\title{
El príncipe christiano del beato Alonso de Orozco
}

\section{INTRODUCCIÓN}

Este tratado se encuentra incompleto y malogrado, como lo fue la vida del príncipe Carlos, al que dedicó una carta de su Epistolario christiano para todos los estados. Epístola primera. Al muy alto y muy poderoso Señor. El Príncipe de Castilla Don Carlos ${ }^{1}$, que viene a ser una maqueta o resumen de este opúsculo. Dicha carta se recapitula en seis avisos, que en parte coinciden con los seis capítulos del Príncipe christiano. No quiso convertir la carta en libro para no ser causa de hastío; pero sí hace un desarrollo más completo, que en su origen se planificó en tres tratados, aunque luego no se cumple de hecho sistemáticamente, sino de un modo impreciso. El mismo Alonso de Orozco reconoce en el capítulo $1^{\circ} \mathrm{o}$ introducción que "aunque parezca intitulado y ordenado para reyes, príncipes y señores, que tiene vafallos y señorío, también es para cada un christiano, el qual a de gobernar christiana y sabiamente su monarquía o reyno que es a fí mismo" ${ }^{2}$.

No se trata de un opúsculo inédito, como se le considera a veces, ya que fue publicado por el P. Tirso López en 1889 con una breve introducción, poniendo como subtítulo: "Fragmento de un manuscrito del beato Alonso de Orozco". Se inclina por considerar que el mismo autor lo dejó imperfecto, aunque reconoce que "no es fácil saberlo" ${ }^{3}$. Lo cierto es que esta publica-

1. A. De Orozco, Obras del Ven. Siervo de Dios Fr. Alonso de Orozco del Orden de N.P.S. Agustín, 1 (Madrid 1736) 1-16.

2. Archivo de la Provincia Agustiniana de Filipinas, Valladolid (APAF) 925/4-2, f. 1v. En adelante lo denominaremos Ms. A.

3. T. LóPEz, "El príncipe cristiano. Fragmento de un manuscrito del Beato Alonso de Orozco", La Ciudad de Dios 20 (1889) 110-17; 225-42 y 289-95, que denominados con la letra B. coincide mucho con una copia existente en APAF 926/1-0, que se cita como Ms. C. Lleva por 
ción ha sido en parte desconocida y merece la pena reeditar el Ms. conforme a la grafía original, algo que no respetó el P. Tirso López. Además de una introducción más amplia, se ponen las notas correspondientes.

Sorprende un poco que su mejor biógrafo, el P. Tomás Cámara, considere al beato Alonso de Orozco como escritor de nuestra edad de oro, filósofo, teólogo, escriturario, asceta y predicador ${ }^{4}$, echándose de menos un capítulo o apartado sobre su aportación canónica y jurídica, cuando es en esta materia, donde estaba más capacitado y va a lograr más altas cotas. Había estudiado durante ocho años, desde 1514 hasta 1522, Leyes y Cánones en Salamanca antes de entrar en la orden de San Agustín ${ }^{5}$, siendo en esta temática muy superior a fray Luis de León, que estudió sólo dos años Derecho Canónico, desde 1541 hasta 1543, en la misma Universidad de Salamanca, donde compuso su tratado de De legibus ${ }^{6}$ en $1570-1571$.

\section{a) Época de la composición y fuentes del "Príncipe christiano"}

Al ser nombrado predicador real el 13 de marzo de 1554 por Carlos v, a quien aconsejó en momentos difíciles y le dedicó grandes elogios, tuvo que reflexionar largamente sobre el tema de la Instrucción de Reyes, donde recoge especialmente sus enseñanzas a Felipe II, al que dedicó los tres tratados

título Libro llamado Príncipe Cristiano por el Beato Alonso de Orozco, $27 \mathrm{ff}$. de $27 \times 18 \mathrm{cms}$. Tiene buena letra y grafía moderna. Es de finales del siglo XIX, anterior a 1889. Se ha considerado aún inédito este Ms. del Príncipe christiano, porque Manuel Villegas lo menciona sin decir que está publicado, "Teólogos agustinos españoles pretridentinos" Repertorio de Historia de las Ciencias Eclesiásticas en España, 3 (1971) 344. En 1970, lo consideraba inédito el P. Antonio García y García, recomendando su publicación con un estudio especial.

4 T. CÁmara, Vida y escritos del Beato Alonso de Orozco (Valladolid 1882) 444-51.

5. H. De Rojas, "Relación sobre la vida del Ven. P. Fr. Alonso de Orozco", Revista Agustiniana 1 (1881) 87. Fueron sus profesores Pedro de la Puebla, catedrático en prima de Cánones; Juan de Olarte, en Derecho; Juan de Monleón y Jerónimo Álvarez, en Vísperas de Cánones; Juan de Castro, en el Libro Sexto y Clementinas; Lorenzo Galíndez de Carvajal, en Prima de Leyes; Alonso de Zúñiga y Fernando Rodríguez de S. Isidro en Vísperas de Leyes; Gaspar de Montoya, Benito de Castro y Pedro de Peralta, en Instituta; Benito de Castro y Francisco de Frías, en Código; Francisco Álvarez de Tapia, Antonio de Benavente y otros, en Cursatorias. Cfr. E. EsPerabé Arteaga, Historia de la Universidad de Salamanca II (Salamanca 1917) 28594. A. de Benavente y P. de Peralta lo fueron también de fray Luis de León. L. Ma HerRán, La Mariología del Beato Alonso de Orozco (Toledo 1991) 16, donde da la lista de sus posibles profesores de Artes y Teología (1523-1530) con las Cátedras Cursatorias. Se limita a observar que en la Universidad de Salamanca "parece estudió Derecho". Cita a T. CÁmARA, Vida y escritos, 23.

6. L. DE LEÓN, De legibus o tratado de las Leyes 1571, Introducción y edición crítica bilingüe por Luciano Pereña (Madrid 1963) XXXVIII + 148 pp. Fray Luis de León es más metódico y sistemático que Alonso de Orozco. Esto se explica por su labor docente. Ver lista de sus profesores de Cánones, ibid. XV; E. Esperabé ArTEAGA, Historia de la Universidad, II, 385--89. 
de la Regalis Inftitutio ${ }^{7}$, sintetizados magistralmente en tres densos capítulos y en forma de Diálogo entre un Agustino y un Cortesano. Coinciden en parte con los tres tratados planificados en el Príncipe christiano, que tiene distinto orden y titulación, como luego veremos. La materia se desarrolla más ampliamente en Regalis Inftitutio, a cuya obra pudiera servir de complemento, ya que es posterior, lo mismo que Epistolario christiano.

En la carta "a su Alteza el Príncipe nuestro Señor" (Carlos) le aconseja leer libros buenos, especialmente el Deuteronomio, que debía tener a su lado: "Deuteronomio quiere decir ley fegunda, porque en aquel libro fumó Moysés la ley de Dios. También me han dicho que Vueftra alteza paffa (lee) el libro, que fe dice Regalis Inftitutio, que yo institulé a fu Mageftad, y aunque algunas veces lee en la Reina Sabá historia etc. ${ }^{8}$, que fue dedicado a la "Reina Católica Doña Isabel de Valois". Esa carta es posterior al 10 de enero 1567, en que se la licencia para publicar el Epistolario, al que se menciona. Regalis Inftitutio es una de las obras que escribió a petición o por orden de la Santísima Virgen entre 1563 y 1565 . No se encuentra ninguna referencia explícita en el Príncipe christiano a Regalis Inftitutio. Tampoco se ve lo contrario, es decir, una referencia en Regalis Inftitutio al libro sobre el Príncipe christiano, que parece ser posterior y da por supuesto lo allí tratado. Es tal la afinidad entre ambas obras que Bonifacio del Moral, al leer las primeras líneas creyó ver en el Príncipe christiano "la traducción del Regalis institutio" "; pero luego advirtió, al cotejarlos, que se trataba de escritos distintos.

Aunque Alonso de Orozco no fue tutor, ni ayo o maestro del príncipe Carlos, cargo que desempeñó el P. Juan de Muñatones, se relacionó muchó con él, lo mismo que con Felipe II, como capellán y predicador, según se comprueba por la primera carta del Espistolario christiano, dirigida "al muy.

7. Se editó por primera vez en Madrid 1565, un tomo en $4^{\circ}$, con cuatro hojas, sin fol. y 76 . En el f. 66 se lee: "COMIENZA vn diálogo, en el cual se suman los tres tratados de esta instrución de Reyes, ordenado por el mismo autor a petición de vn cortesano ". El originatetenía el título de Regalis instructio, que en la licencia real del 20 de diciembre de 1564 se sustituye por Institutio y luego se puso Regalis Inftitutio, como en el tomo IV de Opera ven. P. Fr. Ildefonsi ab Orozco (Madrid 1736) 60 p. Utilizaremos esta edición en las citas correspondientes.

8. A. De Orozco, Obras, I, f. 2v. (sin foliación), donde se hacen algunos elogios al príncipe Carlos, que rezaban cada día "el oficio divino" (f. 2 r) y leía los libros mencionados anteriormente. Esta carta, escrita en 1567, debió de ser dedicada al príncipe para darle ánimo. Le desea "largos tiempos" y "un trono en el Cielo". Firma: "Capellán de Vuestra Alteza" (f. 3v).

9. B. DEL MORAL, "Catálogo de escritores agustinos, portugueses y americanos", La Ciudad de Dios 18 (1889) 663-64. Hay publicación o tirada especial de la segunda parte II, 150, donde se afirma también lo siguiente" " $Y$ es una lástima que se halle incompleto, pues sólo se conservan seis capítulos, y de éstos el último se encuentra truncado". Cf. A Blanco, Biblioteca bibliográfico-agustiniana del Colegio de Valladolid (Valladolid 1909) 436. 
alto y muy poderoso Señor el Príncipe de Castilla don Carlos”. Esta carta, es posterior a la estancia del emperador Carlos V en Yuste y su muerte (1558) que se mencionan, poniéndole como ejemplo. Sabía que el príncipe Carlos admiraba mucho a su abuelo, mientras que tuvo grandes diferencias con su padre, por lo que le procuró aconsejar y orientar como capellán, siendo muy estimado y querido por Felipe II. Le aconsejaba la lectura de las Sagradas Escrituras, "que el príncipe ha de leer y tener a su lado, como el mejor de los libros" ${ }^{10}$. Esta carta es posterior a 1558 y anterior a 1567 en que se publica por primera vez. Según D. Pascual de Gavangos y Enrique de Vedia, traductores y adicionadores de M.G. Ticknor, el Espistolario christiano, "es quizás la más notable de Fr. Alonso de Orozco. Escribe con gran pureza de dicción y su estilo severo y grave brilla en esta última obra más que en la Crónica etc." "11. Opinión, que no comparte el P. Tomás Cámara, aunque reconoce que "es de lo más excelente en el decir; mas como obra literaria, por su propia índole no puede tener la unidad y la perfección que la Historia de la Reina Sabá" ${ }^{12}$. Dejando a un lado qué obra es mejor y si el Príncipe christiano es anterior o posterior al Espistolario, no cabe duda de que es de la misma época, entre 1558 y 1568.

El Príncipe christiano tiene las mismas fuentes que Regalis Inftitutio y "Epístola primera" del Epistolario. Es más, probablemente se trata no sólo de una maqueta de ambos, sino también el proyecto de una gran obra en castellano, que completó y publicó sólo en la lengua de lacio para que pudiera ser leída por los intelectuales de su tiempo, como se estilaba entonces. El Príncipe christiano se planificó para que lo leyesen también los simples cristianos y lectores castellanos. Tiene sus fuentes en la Biblia, en el Derecho

10. A. DE Orozco, Obras, I, 10. La carta ocupa $16 \mathrm{ff}$. El P. Teófilo Aparicio reconoce el valor del Epistolario christiano dedicado al príncipe Carlos: "La corona de España que tanto pesaba en los fatigados hombros de Felipe II, estaba destinada a recaer sobre los de un joven, el príncipe Carlos, cuya vida está aún por aclarar, envuelta en luces y sombras". Fray Alonso de Orozco, hombre, sabio y santo 1591-1991 (Valladolid 1991) 158. El príncipe Carlos fue detenido por orden de su padre Felipe II, el 21 en enero de 1568, debido a un posible complot y presunción de "anormalidad mental" por celos o de otra índole, con "gran pena" de la reina Isabel de Valois, que sentía cariño hacia el príncipe y viceversa. Murió el 25 de julio de 1568 a la 1 de la mañana. Fue atendido religiosamente durante su cautiverio por fray Diego de Chaves. Cf. L. FERNÁNDEZ y FERnÁndeZ DE RETANA, Historia de España. Dirigida por R. Menéndez Pidal, 19 (Madrid 1966) 743-79.

11. M.G. Ticknor, Historia de la literatura española trad. por P. de Gabangos y E. DE VEDIA, 3 (Madrid 1854) 558. G. DE SANTIAGo VelA, Ensayo de una Biblioteca Ibero-Americana de la Orden de San Agustín 6 (Madrid 1922) 126. En las pp. 121-22 trata de Regalis Inftitutio, haciendo referencia a la supuesta versión castellana, que el mismo autor prometió hacer.

12. T. CÁmAra, Vida y escritos, 448. La Historia de la Reina Sabá fue editada por la Casa de Andrea de Portonariis en Salamanca 1565 y reeditada allí mismo en 1568 y 1575, etc. T. Cámara habla ya de cuatro o cinco ediciones en la vida del autor, ibis., 179 y 398. 
Romano y Canónico, Santos Padres, la Escolástica, etc. Conocía el De regimini principum de Egidio Romano ý sus seguidores agustinos en España ${ }^{13}$; a El Príncipe de Nicolás Maquiavelo, al que siguen Juan Bodín en la República y los defensores del "tacitismo" con un carácter político y la llamada "razón de Estado". Esto lo margina Alonso de Orozco, para quien el Estado tiene que atenerse a la ley divina y natural. Tuvo otro antecedente en $E l$ Príncipe de Erasmo, compuesto para formar al emperador Carlos $\mathrm{V}^{14}$.

\section{b) El manuscrito utilizado, su origen y estado de conservación}

El Ms. sobre el Príncipe christiano, escrito por el mismo Alonso de Orozco y utilizado para esta publicación, se encuentra en el Archivo de la Provincia de Filipinas, Valladolid, citado anteriormente, según la catalogación hecha por el P. Manuel Merino entre los años de 1980 y 1987.

El Ms. procede del convento de las religiosas agustinas de Madrid, denominadas Las Magdalenas y actualmente del beato Alonso de Orozco, ya que fueron fundadas por él mismo con la ayuda de Baltasar Gómez, natural de Maqueda. Se hizo esta fundación en 1569 en la calle de Atocha, frente a la iglesia parroquial de San Sebastián, teniendo a sus espaldas la calle de la Magdalena, a la que dio nombre el convento. Intervinieron en la fundación algunas monjas del monasterio de Santa Ursula de Toledo y otras del convento de Gracia de Ávila. Al ser arrojados los agustinos del convento de Doña María de Aragón en 1813, tanto los restos de Alonso de Orozco, como sus manuscritos, pasaron al convento de la Magdalena, donde estuvieron hasta el 23 de agosto de 1825, en que se recuperó el colegio de María de Aragón, donde volvieron a estar hasta la desamortización, el 17 de diciembre de 1835 . Las agustinas de la Magdalena se hacen cargo de sus manuscri-

13. F. Rubio, "De regimine principum de Egidio Romano en la literatura castellana de la Edad Media", La Ciudad de Dios 174 (1961) 645-67. Alonso de Orozco cita al De regimine principum en Regalis Inftitutio, trat. III, cap. 31. p. 53. Entre los agustinos que le siguen están fray Francisco Castelló, fray Juan de Alarcón y fray Martín de Córdoba. Cf. F. CAMPo, "Allegationes sobre la potestad eclesiástica. Opúsculo inédito de Fray Francisco Castelló", Estudio Agustiniano 10 (1975) 455-89.

14. N. Machiavelo, Il Principe (Roma 1532); D. ERASMus, Institutio principis christiani (Basilea 1516). Hay varias traducciones, como la de L. RIBER, Educación del príncipe cristiano (Barcelona 1985) con "Querella de la paz" y "Correspondencia a los monarcas reinantes" como la carta al Emperador Carlos V en 1522 (pp. 145-48). Sobre la razón de Estado ver F.R. ORTIZ, "Tacitismo", Gran Enciclopedia Rialp, 22 (Madrid 1975) 24-5. Han podido servir de fuentes las obras de Antonio DE GuEvarA, Libro ávreo de Marco Aurelio, Emperador eloquentíssimo (Sevilla 1528) y Relox de príncipes (Valladolid 1529). 
tos, que peregrinaron con ellas, primero al monasterio de la Encarnación, luego al de la Concepción Jerónima y Cristo de Medinaceli, mientras que sus restos se quedaron en la iglesia de San Sebastián hasta su traslado al convento de agustinos en Valladolid el 23 de septiembre de 1853, por ser el único convento de los agustinos que subsistió a la desamortización ${ }^{15}$.

Los manuscritos siguieron en poder de las Agustinas Magdalenas, hasta que el P. Tomás Cámara, siendo obispo de Salamanca las procuró conseguir unos terrenos en Goya 87 de Madrid para construirlas un nuevo convento con la ayuda de los condes del Vall en 1888. Ese mismo año se trajeron los manuscritos, entre ellos el Príncipe christiano para el archivo del convento de agustinos en Valladolid. Fue visto por el P. Cámara antes de 1882, ya que lo menciona entre los manuscritos autógrafos de Alonso de Orozco ${ }^{16}$.

Dado el itinerario y avatares, por los que han pasado sus manuscritos, es normal que falte alguna hoja al final. ¿Cuántas hojas faltan? No se sabe. Lo cierto es que debía seguir por lo menos otra, ya que no termina la frase y llega al final del texto, con el artículo "el..." que reclama un sustantivo y algo más para completar el punto referente al dominio de sí mismo, como algo necesario para vencer a sus enemigos, apetitos e inclinaciones ${ }^{17}$.

El estado del manuscrito del Príncipe christiano es bastante bueno. Se trata de un cuadernillo en $4^{\circ}$ de 14 folios de $22 \times 15,5 \mathrm{~cm}$. Hacia la mitad del texto, están dañados los folios 1 x $3 \mathrm{~cm}$. en la parte derecha, faltando las últimas letras de las palabras en 4 ó 5 líneas, lo que se sobreentiende fácilmente. Lo dañado se debe a causas desconocidas. Esto ha sucedido probablemente después de 1889 , ya que no se hace referencia a esta circunstancia, ni se tuvieron problemas para su lectura. Debió tener más hojas al final en blanco. Actualmente sólo hay una y está suelta, por lo que bien ha podido desaparecer alguna escrita o dejarlo así el autor.

Algunas notas aparecen incompletas al margen, algo que se respeta, incorporándolas al texto entre paréntesis y desarrollándolas abajo más ampliamente. Se dan las citas bíblicas conforme al texto de la Vulgata de san Jerónimo, utilizado por el autor, que conocía el hebreo y el griego. Hay notas, que se dan ad sensum, sin poderse precisar en un capítulo y versículo

15. T. CÁmara, Vida y escritos, 560-67. El P. Manuel Merino, que falleció el 27 de agosto de 1987, revisó todos los escritos del beato Alonso de Orozco y los catalogó con una técnica moderna, colocándolos en cajas o estuches especiales. Ver supra notas 2 y 3 . Le sorprendió la muerte mientras estaba recopilando datos sobre la canonización del beato Alonso de Orozco y las publicaciones posteriores.

16. T. CÁmARA, Vida y escritos, 437. Intervino también el P. Arsenio del Campo.

17. Ms. A., f. 14v. En el Ms B, f. $27 \mathrm{v}$. aparece "él". Se hace lo mismo en el texto publicado por T. LóPEZ, "El príncipe cristiano", 295. 
determinado, como sucede con la cita, que atribuye al apóstol san Pablo: "Siempre andan a la efcuela y jamás alcançan la fabiduría perfecta" ${ }^{18}$.

\section{c) Contenido del "Príncipe christiano" y relación con "Regalis Inftitutio"}

Sin prólogo, ni advertencias preliminares, entra de lleno en la materia haciendo una planificación de la obra en tres tratados, como tres son las potencias del alma y los tres avisos del santo y sabio rey David con los que comienza el libro. El mismo especifica los tres tratados así: "En el primero se tratará qué cofas han de considerar los reyes christianos para cumplir con dignidad de su ofiçio. En el segundo se verá la fabiduría que a de tener el que es príncipe y govierna alguna república. Finalmente en el terçero y último tratado se verá el arte, que para servir a Dios, da este sancto profeta no a los reyes christianos, más aun para todos nofotros; tan obligados a loar y servir a nuestro Dios y criador, de quien tenemos tantos y tan grandes venefiçios reçibidos" ${ }^{19}$. Estos tres tratados se iban a ordenar conforme a los tres avisos del profeta David.

En realidad, no coinciden estos tres tratados con los de_Regalis Inftitutio, cuyos títulos son los siguientes: $1^{\circ}$ "De la sabiduría y virtudes que ha de tener el Rey"; $2^{\circ}$ "De la governación de la cafa y familiares" y $3^{\circ}$ "De cómo ha de governarse el Reyno" ${ }^{20 .}$ La "sabiduría", que aparece en primer tratado de Regalis Inftitutio se propone como tratado II del Príncipe christiano, sin que aparezca como título en ninguno de los seis capítulos, aunque se hace referencia a ella en el contenido del capítulo $4^{\circ}$ al tratar "Del ofiçio que a de tener el prínçipe christiano", donde se menciona la sabiduría de Salomón, algo que deben tener los que gobiernan ${ }^{21}$.

En el fondo se desarrollan en parte los tres avisos, como luego veremos, sin haber una clara delimitación de los mismos. Al principio aparece este título: "Comiença el libro llamado Príncipe christiano", donde no se pone capítulo $1^{\circ}$, y viene a ser una especie de introducción con el plan de la obra, que pensó desarrollarse en forma de tratados y de hecho aparece una nota

18. Ms. A, f. 3r. Se debe referir a 1 Cor, 1,21 y 2,6, ya que los de Corinto se consideraban sabios sin serlo en cuanto a lo espiritual, por lo que pregunta san Pablo en 1Cor 1,20: "¿Dónde está el sabio? ¿Dónde la sabiduría? etc.

19. Ms. A, f. 1v.

20. A DE OROzCo, "Diálogo entre Agustino y un Cortesano, en el qual se suman los tres Tratados de la Inftrucción de Reyes. Ordenado por el mifmo Autor, a petición de un Cortefano", Obras, I, sin foliar, 7 f. Cfr. Regalis. Inftitutio, 3, 30 y 41, donde se ponen los títulos en latín.

21. Ms. A, f. 8r. 
del mismo autor, puesta sobre el texto, como encabezamiento, casi al final de lo que el P. Tirso López tituló "Capítulo primero"; aunque en realidad viene a coincidir con el final de lo que sería introducción y antes de lo que podría ser "capítulo primero", con este título "Prínçipe christiano. Tratado primero" 22 .

Cada cristiano y ciudadano es un rey con tres facultades, a semejanza de tres provincias que debe gobernar: memoria, entendimiento y voluntad, a las que se hace referencia en el salmo de David, anteriormente citado, y dan origen a tres tratados. Algo que no aparece claro en el Príncipe christiano, porque no está completo o porque el autor no siguió el plan propuesto.

El contenido del capítulo $2^{\circ}$ viene reflejado en su título: "Cómo de Dios, Rey soberano, tienen la dignidad los reyes" ${ }^{23}$. Todo poder viene de Dios. Se da un texto bíblico que sirve de fundamento al primer tratado. Todo lo que tenemos lo hemos recibido de Dios. Esto deben saberlo los reyes, grandes señores y todos los cristianos.

En el capítulo $3^{\circ}$ se pone como modelo de reyes y verdadero rey a Jesucristo, el Señor de las virtudes y rey de la gloria. La verdadera sabiduría que se trató en el capítulo anterior se complementa con las virtudes, que ha de tener el rey. Ha de tener especialmente amor y misericordia. El título de este capítulo es: "Del gran reino de nuestro Redentor Jesucristo" ${ }^{24}$. Esto se aclara con textos del Viejo y Nuevo Testamento. Los cristianos son hijos de Dios y deben estar adornados con las virtudes debidas.

El capítulo $4^{\circ}$ "Del oficio que a de tener el príncipe christiano" ${ }^{25}$, comienza con una referencia a la reina Sabá, a la que se menciona en el segundo tratado sobre la gobernación de la casa y familia. Fue objeto de un libro especial y uno de los mejor logrados, como se ha visto anteriormente. El rey tiene que hacer justicia con fortaleza de ánimo, oyendo antes a las partes. $\mathrm{Ha}$ de actuar como médico, que tiene que curar y operar. Cuando sea necesario hay que castigar a los malos para conservar la paz. En parte esto es lo que se desarrolla en el tratado tercero de la Regalis Inftitutio sobre "cómo ha de gobernar el rey" o De cura política ${ }^{26}$.

El buen gobierno debe comenzar por uno mismo y por eso el capítulo $5^{\circ}$ se titula: Cómo el rey a de enseñorear a sí mismo ${ }^{27}$, que es uno de los más interesantes y novedosos. Si la salvación ha de comenzar por uno mismo y

22. Ibid., f. 2v-3r. Cf. T. LÓPEZ, "El príncipe cristiano", 111.

23. Ms. A, f. $3 r$.

24. Ibid., f. $5 \mathrm{v}$.

25. Ibid., f. $8 \mathrm{r}$.

26. A. DE OROzCo, "Diálogo entre Agustino", f. 4r; Regalis Inftitutio, trac. III, cap. 24, p. 41.

27 Ms. A, f. 10r. 
uno salva su alma salvando a los demás, de igual manera, para gobernar bien a los demás, hay que comenzar por saberse gobernar uno mismo. Hay que ver en los súbditos a hermanos y servirles. Tenemos que darnos cuenta de que somos de carne, que es flaca y con sus debilidades, por eso es necesario saber modelar nuestra arcilla y troquelar nuestros instintos bajo la dirección de la razón y con la gracia de Dios. Se nota una orientación pastoral.

El capítulo $6^{\circ}$ De las armas con que el hombre ha de vencer a sí mismo ${ }^{28}$ viene a ser un complemento del anterior. Se recomienda imitar a Jesucristo, el mejor modelo. Hace ver su fortaleza y modo de vencer al mundo mediante un texto de san Agustín. Hay que contar con las armas espirituales. Se vence, como Gedeón a veces con menos, si se cuenta con la ayuda de Dios. Concluye el libro haciendo ver que "el rey fuerte será señor de sus enemigos, si el principal vençiere primero que es rendir a sí mismo sus apetitos y inclinaçiones que le convidan para el" ${ }^{29} \ldots$ (mal)?

Según observa el P. Tirso López, "el último (de los seis capítulos) es más bien fragmentos que un capítulo" ${ }^{30}$. Por lo menos falta la conclusión y cómo han de gobernar los reyes, que en el tercer tratado de Regalis inftitutio, se titula "De cura política" ${ }^{31}$. Esto se resume en el capítulo $3^{\circ}$ del Diálogo entre Agustino y un Cortesano: "El tratado tercero habla con los Reyes, avisándoles cómo han de governar sus Reynos; y creer que fi el Príncipe es virtuoso, temeroso de Dios, y señor de fus pafiones, que efte tal governará bien su casa y también su Reyno. Van muy hermanadas eftas tres ciencias: Ethica, que enfeña las virtudes morales; Económica, que da avifo para governar cada uno fu cafa. Y Política, que enseña a regir bien la República o Reyno" ${ }^{32}$. En estas materias debe capacitarse también el príncipe cristiano, que ha de tener en cuenta las enseñanzas del rey David, de los Evangelios, de san Pablo, de la filosofía griega, especialmente de Aristóteles, al que califica de "el filósofo" ${ }^{33}$, de san Agustín y demás santos padres, de santo Tomás y del Corpus iuris canonici, tal como era explicado en la Universidad de Salamanca, donde se había formado y vivido momentos dramáticos, como fue el Movimiento Comunero, apoyado por muchos salmantinos, como su profesor de Vísperas de Leyes, Alfonso de Zúñiga, que fue procesado por su implicación en la sublevación comunera ${ }^{34}$. Eran salmantinos Francisco y Pedro Mal-

28. Ibid., f. $12 v$.

29. Ibid., f. $14 \mathrm{v}$. Sobre el texto de san Agustín ver infra nota 106.

30. T.LÓPEZ, "El príncipe cristiano", 110.

31. A. DE OROzCO, Regalis Inftitutio, trac. III, cap. 24, p. 41.

32. A. DE Orozco, "Diálogo entre Agustino", f. 4r.

33. Príncipe christiano, cap. 5. Ms. A, f. 11r. 
donado, pertenecientes a una familia noble y ejecutados, el primero un día después de la derrota de Villalar y el segundo a mediados de agosto del año siguiente en la plaza de Simancas.

\section{d) Influencia de la doctrina de Alonso de Orozco y sus seguidores}

Su doctrina coincide con la de sus maestros y condiscípulos de Salamanca. El hecho de que esta obra esté incompleta y no fuese publicada en el siglo XVI, dificulta la posibilidad de precisar su influencia directa, aunque sí la tiene indirectamente, como Regalis Inftitutio, su resumen en el Diálogo entre un Agustino y un Cortesano y la "Epístola primera al muy alto y muy poderoso Señor el Príncipe de Caftilla Don Carlos" de su Epistolario christiano para todos los estados, con el que tiene mayor afinidad, como ya se ha observado anteriormente y veremos también en la conclusión.

Tuvo influencia dentro de su Orden, entre sus hermanos de hábito, y también entre escritores notables de su época, como Francisco de Quevedo, que fue uno de sus grandes admiradores y autor de la Política de Dios. Govierno de Cristo ${ }^{35}$, donde sigue la doctrina desarrollada por Alonso de Orozco en el Príncipe christiano y en Regalis Inftitutio.

Entre los agustinos, que se inspiran o siguen al beato Alonso de Orozco, están fray Luis de León, en los Nombres de Cristo ${ }^{36}$ y en su tratado De Legibus $^{37}$, al que sigue su discípulo fray Pedro de Aragón en la obra De Justitia et Jure; fray Marco Antonio de Camós en su obra Microcosmia y govierno uni-

34. V. Beltrán DE Heredia, Cartulario de la Universidad de Salamanca, III (Salamanca 1971) $98-99$ y 101-114.

35. F. DE QUEvedo, Política de Dios. Govierno de Cristo (Madrid 1867). Conoció en su infancia al beato Alonso de Orozco y le tuvo "por persona de gran santidad y méritos, y como tal fue venerado con demostraciones públicas de todos, asi en la Iglesia, como en la celda, o en las calles, las pocas veces que por ellas se veía". Informe Sumarial de Madrid, f. 465. Cf. T. CÁMARA, Vida y escritos, 269.

36. A. DE OROzCO, Los nombres de Cristo, APAF, 926/2-6. Copia hecha a finales del siglo XIX del manuscrito original de Alonso de Orozco, que dicen desapareció durante la guerra de 1936 en El Escorial. Cf. M. De la Pinta Llorente, "En torno a Fr. Luis de León (Polémicas y controversias)" Crítica y humanismo (Madrid 1966) 89-107. Quizás aparezca aún el original. Sobre esto hay abundante bibliografía y disparidad de opiniones.

37. L. Pereña, "Introducción" a De legibus, de fray Luis de León, XXXII-XXXV, donde se dice que Pedro de Aragón sigue también a Juan de Guevara. Un sobrino de fray Luis de León, fray Basilio Ponce de León, fue gran admirador del beato Alonso de Orozco, como lo reconoce en las notas que puso a sus Confesiones, edic. por L. RUBIO, 175, donde afirma que "fue afamadísimo teólogo, y la destreza, brevedad y claridad con que habla en materias bien delgadas, lo dicen bien claro". El beato Alonso de Orozco fue un hombre enciclopédico y recapitulador, por lo que tuvo muchos lectores y seguidores. 
versal del hombre cristiano para todos los estados y qualquiera de ellos, etc. ${ }^{38}$; y sobre todo, fray Juan Márquez, uno de sus biógrafos y autor de El governador cristiano, deducido de las vidas de Moysés y Iosvé, príncipes del pveblo de Dios. Lo dirigió el Duque de Feria, D. Gómez Suárez de Figueroa y Córdova ${ }^{39}$. Esta obra, que cuenta con diez ediciones, es un complemento de la del beato Alonso de Orozco e incluso superior en su contenido y exposición sistemática. Un compendio de los principios de gobierno y moralidad pública defendida por estos religiosos agustinos se encuentra en las obras de fray Pedro Maldonado ${ }^{40}$, fray Enrique de Mendoza y fray José Laínez ${ }^{41}$. Esta lista podría ser aumentada, porque este género literario, canónico y moral tuvo muchos seguidores entre los agustinos y miembros de otras congregaciones, como Pedro de Rivadeneira ${ }^{42}$, que se enfrentó con los seguidores de Maquiavelo y los llamados "tacitistas" defensores del Estado político o "razón de Estado", materia, que fray Juan Márquez consideró, "materia agena de su profesión" según declara en el preliminar "al lector" de su governador christiano ${ }^{43}$. Tanto Alonso de Orozco, como los agustinos mencionados, aunque seguían fieles a la doctrina de san Agustín sobre la colaboración de la Iglesia y el Estado confesional o el llamado "Agustinismo Políti-

38. M.A. CAmos, Microcosmia y govierno del hombre christiano para todos los estados y qualquiera de ellos (Barcelona 1592). Está dedicada esta obra al duque de Sessa y Soma, D. Antonio de Cardona, al que trató en Madrid, lo mismo que al beato Alonso de Orozco, cuyos escritos conocía.

39. J. MÁrQueZ, El governador christiano, (Salamanca 1612). Está dedicada al duque de Feria, que en una carta de presentación, fechada en Medina del Campo, 11 de junio de 1606, narra la génesis de esta obra y sus posibles antecedentes, ff. 4-5 sin numerar.

40. Q. FERNÁNDEZ, "El padre maestro fray Pedro Maldonado OSA (1576-1614) y su opúsculo inédito, Tratado del perfecto privado", Archivo Agustiniano 60 (1976) 217-29, donde se hace ver su relación con las obras de otros agustinos. Comete el error de considerarlo inédito, cuando éstaba ya publicado por F. RuBio en Anuario Escurialense, 4 (1963) 757-803.

41. E. DE MENDOZA, El privado christiano (Madrid 1626): J. LAÍnEZ, El privado cristiano deducido de las vidas de José y Daniel (Madrid 1641); El Daniol cortesano etc. (Madrid 1644), y Josué, esclarecido caudillo, vencedor de Reyes y gentes, etc. (Madrid 1653). Las dos últimas obras vienen a ser una continuación de la primera, ya que su autor se propuso completar la obra de Alonso de Orozco y fray Juan Marquez. Quien quiera ver en estas obras una orientación netamente política, se encontrará con que son más bien de carácter bíblico, moralizador, canónico y ético. Influyó también en Juan de Mariana, De Rege et Regalis Institutione (Toledo 1589). Cf. L. Mª . Herrán, La Mariología del Beato Alonso de Orozco, 23-24.

42. P. DE RIBADENEYRA, Tratado de la religión y virtudes que debe tener el príncipe cristiano para governar y conservar sus Estados. Contra lo que Nicolás Machiavelo y los políticos de este tiempo enseñan (Madrid 1595). Hace referencia al "tacitismo" y a la llamada "razón de Estado".

43. J. MARQUEZ, El governador christiano, "Al lector" f. $3 \mathrm{r}$, sin numerar.

44. H.X. Arquiliére, L'Agustinisme Politique. Essai sur la formation des theories du Moyen Âge (Paris 1934) 68-93; F. CAMPO DEL Pozo, "El agustinismo político en España durante la Edad Media", Augustinus 25 (1980) 181-207. 
co" ${ }^{44}$, estaban animados por un espíritu evangélico y pastoralista en la edifi- । cación de la Iglesia y del Estado cristiano.

Se da por admitida o supuesta la doctrina bíblica de que toda potestad viene de Dios, lo que se constata con textos del Viejo y del Nuevo Testamento. Hay referencias al poder político y modo de gobernar a la República y los súbditos. La actividad política ha de ordenarse al bien del pueblo, de la Iglesia y de Dios. Se evoca el ejemplo del pueblo judío y el de Roma. Alonso de Orozco supone la potestas política, que desarrolla mejor en Regalis Inftitutio, donde justifica el derecho a la guerra para ampliar la fe, como sucedió en la conquista del reino de Granada; y para detener o extirpar la herejía, como hizo el emperador Carlos $V$ en Alemania ${ }^{45}$. El príncipe cristiano ha de acudir a las enseñanzas de la Biblia, de Jesucristo, de sus discípulos y de la misma Iglesia. Puede y debe imitar también a los romanos con sus leyes y cónsules elegidos por el pueblo. Siguiendo a Aristóteles, defiende que es mejor la aristocracia, que la democracia, sin proponerse la problemática de que la potestad viene de Dios a través del pueblo, algo que desarrollaron mejor sus seguidores, como Fray Luis de León, fray Pedro de Aragón y otros profesores salmantinos, que dieron pasos decisivos hacia la democracia y el Derecho de gentes.

Alonso de Orozco conocía los problemas del ius gentium y la evangelización de las Indias, ya que entre sus planes estuvo el de ir de misionero a México, para donde se embarcó en 1548, teniéndose que quedar en Canarias por la enfermedad de gota artética: Menciona en sus escritos la evangelización de las Indias, sin plantearse en este libro, ni en Regalis Inftitutio, los derechos de los indios y el ius gentium, defendidos por los profesores salmantinos y algunos de sus hermanos de hábito, como fray Alonso de Veracruz, fray Luis de León, fray Bartolomé Salón y otros ${ }^{46}$.

45. A. DE OROzCo, Regalis Inftitutio, trac. I, cap. 14, pp. 23-24. Fray Luciano Rubio promete "publicar tres series de escritos en torno al beato Alonso de Orozco, personaje un poco preterido, con ocasión del cuarto centenario de su muerte (19 de septiembre de 1991). En la primera serie, las fuentes documentales para el estudio de su biografía. En la segunda serie, historia de su biografía, de sus escritos en general y de sus doctrinas. En la tercera serie,ediciones modernas de todas o algunas de sus obras". Advertencia preliminar a las Confesiones del Beato Alonso de Orozco, (Madrid, Real Monasterio de El Escorial, 1990) f. I.

46. A. DE Orozco, Confesiones, lib. III, cap. 9, edic. por L. Rubio, 107; Cf. T. CÁmara, Vida y escritos, 105; B. DifERNAN, "Miguel Bartolomé Salón, fundador del Derecho Internacional" Revista Española de Derecho Internacional, 6 (1953) 83-126; F. CAMPo DEL Pozo, Los Agustinos en la Evangelización de Venezuela (Caracas 1979) 173-77, donde puede verse la doctrina de fray Alonso de Veracruz, fray Alfonso de Mendoza, fray Jerónimo Román y otros. Uno de los mayores defensores de los derechos de los aborígenes fue fray Luis López de Solís. Cf. L. PEREÑA, Carta magna de los indios (Madrid 1987) 286-93. 
Él trata el tema de las leyes, que deben ser justas, su concepto y promulgación en Regalis Inftitutio, donde se preocupa también de las penas para castigar a los infractores y conservar el orden. Los reyes, como los jueces y príncipes, han de actuar con clemencia, promoviendo el bien de las ciudades y sus habitantes. Justifica el tener ejército para defender el reino y los reyes, que deben tener su escolta o soldados para su seguridad y la de sus súbditos ${ }^{47}$.

Las armas, con que el príncipe y todo hombre ha de vencerse a sí mismo son las virtudes, que se desarrollan más ampliamente en los caps. XI-XIV de Regalis Inftitutio, donde dedica el cap. XV a exponer en concepto de justicia y el cap. XVI al dominio de las pasiones ${ }^{48}$, tema con el que concluye el Príncipe christiano, sin darse una solución clara y precisa por estar incompleto. Según Alonso de Orozco, para modelar nuestra arcilla y troquelar las pasiones, son necesarias la imitación de Jesucristo y la oración.

El Derecho Canónico tiene, como último fin, la salvación de las almas; de igual manera, este libro enseña a salvarse, autogobernarse y modo de gobernar la casa y familia para poder ejercer bien el oficio de rey. Hay que comenzar por saberse gobernar a sí mismo y salvarse que es la verdadera sabiduría. Su lectura se hace agradable, teniendo el grato paladeo de los vinos añejos y el olor de la santidad de su autor.

e) Publicación y transcripción del Ms. con las siglas y signos utilizados

La publicación del Príncipe christiano según el texto original, con las notas complementarias, contribuirá a divulgar su contenido, doctrina y el modo de escribir en su época. Al poner las variantes, cotejando el texto original con el publicado por el P. Tirso López y otra copia manuscrita de finales del siglo XIX, se puede llegar a la fijación del texto. Tiene también importancia filológica y estilística, ya que el castellano del beato Alonso de Orozco es claro, elegante y sencillo, incluso cuando trata de temas morales y jurídico-canónicos como sucede en este libro. Se trata de uno de los orfebres de la lengua española, no en vano forma parte del Catálogo de Autoridades, donde le ha incluido la Real Academia Española, como observa su mejor biógrafo ${ }^{49}$, poniendo de relieve fray Juan Márquez, que "era agudo ẹn las

47. Regalis Inftitutio, trac. III, cap. 29 , pp. 47-54.

48. Ibid., 15-47.

49. T. CÁMARA, Vida y escritos, 457.

50. J. MÁrQueZ, Vida del Venerable P. Fray Alonso de Orozco, III, cap. 6 (Madrid 1648) 12. 
sentencias, propio en las palabras... no forzado en las metáforas y nada inferior en romance y latín a los que con mayor primor escriben en una y.otra lengua" ${ }^{50}$.

En la transcripción se conserva la grafía del original, como se ha observado anteriormente, poniendo los acentos, puntuación y mayúsculas correspondientes para mejor comprensión. El mismo original tiene su puntuación, que en su mayor parte se ha respetado, especialmente en los puntos y aparte. No siempre tiene uniformidad en las letras, que se procuran conservar dentro de lo posible. La "i" latina se escribe a veces como $\mathrm{j}$ y hemos optado por dejarla como " $i$ " latina, distinta de la " $y$ " griega, que se conserva, lo mismo que la " $f$ ", aunque a veces se parece mucho a la "s" alargada. La u es a veces $\mathrm{v}$ y se confunde, por lo que se ha optado por la v, si lo pide el texto. Tanto las comillas como el subrayado, es nuestro.

Se utilizan los siguiente signos:

(...) Incorpora palabras, que aparecen al margen, dentro del texto.

$<\ldots>$ Incluye letras o palabras que se sobreentienden.

[...] Completa el texto, alguna laguna o el folio correspondiente.

Además de la sigla Ms A, ya explicada, se utiliza la letra B para indicar el texto publicado, la $\mathrm{C}$ para la copia de finales del siglo XIX y las letras del abecedario, que se repiten cíclicamente, para las variantes. Se desarrollan las abreviaturas, como sucede con la palabra "xptiano", que equivale a christiano, según aparece en otros lugares del mismo Ms. A.

Sólo se recogen las variantes propiamente tales, no el simple cambio de letras, ya que tanto en el texto B, como en el C, se utiliza generalmente una grafía moderna, salvo algunas excepciones. Aquí se procura transcribir lo más fielmente posible el Ms. A. Se da fotocopia de la primera y última página para que se pueda observar su grafía y lo que se afirma sobre su transcripción. 


\section{[f. 1r] COMIENÇA EL LIBRO LLAMADO PRÍNCIPE CHRISTIA-} $\mathrm{NO}^{\mathrm{a}}$

(Ps. 2). Nunc reges intelligite, erudimini qui iudicatis terram ${ }^{\mathrm{b}}$, servite Domino in timore et exultate ei cum tremore ${ }^{51}$. Quiere dezir el fanto rey David: "aora reyes entended y sed enfeñados los que juzgáis la tierra, servid al señor en temor y alegraos en Él con temblor". Como este excelente rey fue tan agradable a Dios y alcançó delante <de > su Magestad tan crecidos favores, no folo eligiéndole para rey de Isrrael, aún en vida del rey Saúl, su adverfario, más aún comunicándole grandes secretos açerca de la redençión del mundo según pareçe en loś pfalmos c, adonde profetizó claramente la encarnaçión del Hijo de Dios, su natividad, su muerte y pasión, su resurreçión y afcensión, la venida del Espíritu Sancto y la magestad con que a de venir a juzgar nuestro Salvador Jesucristo; de aquí es, que aviéndole Dios tanto engrandeçido y siendo él tan avisado siervo leal de nuestro Criador y Señor, quiera hazerse maestro de todos nofotros, gente tosca y heredada en ygnorançia, nacida del pecado, dándonos avifo y arte como sirvamos al que sirven los serafines en el çielo y aún se hallan inábiles para servir a tal alta Magestad y Rey de infinito poder: digo que habla aquí con todos nosotros, aunque parezca averlo con los reyes y prínçipes, porque cada un cristiano rey es, y su reino es grande y muy noble, pues las potençias del ánima, que son entendimiento, memoria y voluntad; tres provinçias son, las quales an de estar sugetas al imperio de la razón y aún los çinco sentidos corporales reyno es de gran valor [f. 1v] y estima, en cuya governaçión a de aver gran diligençia para que no se rebele y levante contra lo que la sancta fe nos manda y la razón alumbrada con tal luz del çielo enseña, en manera que este libro, aunque parezca yr intitulado y ordenado para los reyes, prínçipes y señores, que tienen vafallos y señorío, también es para cada un christiano, el qual a de governar christiana y sabiamente su monarchía ${ }^{d}$ o reyno que es a fí mismo.

51. Ps. 2,10-11.

a Capítulo primero | add. $\mathrm{B}$

b terram I terras C

c pfalmos I salmos b y C

d monarchía | monarquía B y C 
Tres cosas enseña aquí este sabio y fanto rey, al qual todos los reyes avían de tener por dechado en todas sus cofas: la primera es que entiendan aora; la segunda, que sean enseñados, pues an de juzgar a sus vasallos; la tercera, les amonesta que sean siervos de Dios y dáles el arte para ofiçio tan delicado diziendo que le teman y se gozen en él. Conforme a estos tres avisos, ordenaremos este libro dividiéndole en tres tratados: en el primero se tratará qué cofas an de considerar los reyes christianos para cumplir con la $\mathrm{di}<\mathrm{g}>$ nidad de su ofiçio; en el segundo se verá la sabiduría que a de tener el que es príncipe y govierna alguna república; finalmente en el tercero y último tratado se verá el arte que para servir a Dios da este sancto profeta, no solamente a los reyes christianos, más aún para todos nosotros, tan obligados a loar y servir a nuestro Dios y Criador de quien tenemos tantos y tan grandez benefiçios reçebidos. Dize, pues, el rey David: "aora reyes entended". 52 . Dezir esta palabra aora, es dar a entender que el tiempo para considerar lo que deven los señores a Dios es este presente, y que para sacar utilidad de estas consideraçiones, no se a de dilatar hasta que se acabe esta vida, después de la qual, no será meritorio, sino para [f. 2r] mayor daño, lo que el pecador entendiere. Anfí ${ }^{\mathrm{e}}$ como a los ángeles fe les dio como por efcuela el çielo impíreo ${ }^{\mathrm{f}}$, adonde fueron criados para que en breve, como a criaturas tan ábiles y sabias, se determinasen en llegarse a Dios, o por su voluntad y amor propio llegarse ${ }^{\mathrm{g}}$ a sí mismos ${ }^{\mathrm{h}}$, anfí a los hombres terrenos criados en este suelo dio la divina bondad como por escuela este mundo y el término para conocer, y conoçiendo volverse a su Dios, fue darle todos los días de su vida. Esta ley, que el Señor dio tan diversa a los hombres conçediéndoles tanto término para remediar fus males pafados, fue gran privilegio y particular favor, aunque en gran justiçia fundado; más entiende el ángel por ser folamente espíritu en un momento, que el hombre rudo y tan inábil agravado de este pesado cuerpo mortal en grandes años. Esto es lo que el justo David dixo en un salmo (Ps.): "Quiero Dios vivo ${ }^{i}$ misericordia de nofotros anfí como padre, que tiene compaffión de sus hijos." ${ }^{53}$, el qual se acordó que $^{j}$ éramos polvo. ¡Oh santo Dios! Qué le valiera a un Luçifer un poco

52. Ps. 2,10 .

53. Esta idea aparece en varios salmos de una manera difusa e incompleta, como Ps. 6,5 ; 22,6; 24,7 etc. Está más claro en Oseas, 6, 6 y Mt 12,7.

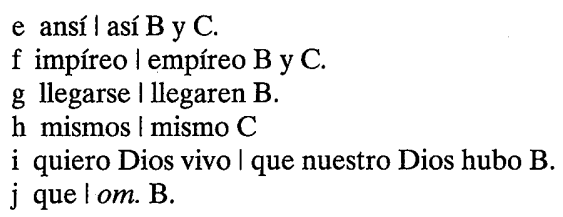


deste polvo que traemos nosotros a cuestas: ¡Oh quánto preçiara el hallarse vestido de carne mortal para que pudiera tener tiempo de dar siquiera un gemydo de verdadera penitençia, por el qual le perdonará Dios su pecado! Cosa ef de notar que nos solemos quexar de lo que avíamos de alabar a Dios y tomar ocasión de más servirle y amarle, tenemos muchas vezes defcontento por hallarnos vestidos y enbarasados con esta vestidura que ef nuestro cuerpo y si bien miramos debaxo desta ceniza, quiso el criador sapientíffimo guardar y conservar la brafa ençendida de fuego de amor de Dios, que es nuestra ánima, la qual como [f. 2v] la candela fuera de linterna, tiene peligro que la mate el cierço, anfí nuestra ánima, si no la infundiera el artífice soberano en esta carne, pecara sin tener remedio, como el ángel pecando una vez quedó condenado para siempre.

\section{(PRÍNÇIPE CHRISTIANO. TRATADO PRIMERO) k}

Entiendan los reyes aora, aprovéchense del tiempo que el Señor del mundo otorgó a los hombres; sepan que en tanto que viven es "tiempo aceptable a Dios y es día de salud" ${ }^{54}$, como nos enseña san Pablo. Gozen del privilegio singular, que el Rey del çielo, nuestro Dios, nos ' otorgó, y no sean defcuydados en tan arduo negoçio. De aquí entendemos dos cosas grandes: la una, la gran piedad y clemençia de nuestro Criador, que cerrando puerta a los ángles que sola una vez pecaron para que no pudiesen tornarse a Dios; al hombre le dexa abierta para que si quisiere enterider y entendiendo siguiere su dignidad y privilegio, por el qual se le conçede tiempo de penitençia, se le dé perdón general de sus culpas y quede hecho un espíritu con Dios; lo segundo, tenemos de lo ya dicho entendido ser en alguna manera la dignidad del hombre más alta que la de los ángeles; en manera que, fi pudiera ser que a my eleçión me dexara Dios ser ángel o ser hombre, yo dixera: Señor, quiero ser hombre y no ángel; la razón ef porque haviendo Dios de hazerse hombre y no ángel, más açertado era en elegir el ser de hombre; también porque con tal ley que el ángel no se le dé primilla pecando, como no se la dieron; y a my la bondad infinita de Dios me perdona y dize a fan Pedro, en nombre de todos los confesores de la [f. 3r] Iglesia que me absuelvan, "no folamente siete vezes, sino setenta vezes siete" ${ }^{55}$, que quiere dezir, quantas vezes con

54. $2 \operatorname{Cor} 6,2$.

55. $M t 18,2$.

k Príncipe christiano. Tratado primero $1 \mathrm{om}$. B y C.

1 nos I om. B. 
verdad hiziere penitençia. Más quiero ser hombre que no ángel. Den los hombres alabanças a Dios, no cesen los señores de considerar este tiempo presente de esta vida quán útil sea, y pues, en esta escuela, los pequeños niños hijos de Adán an fiempre de yr aprovechando, abiven su entendimiento, consideren cosas grandes, porque no les toque aquella reprensión que da el Apóstol a los que viven descuydados diziendo: "Siempre andan a la escuela y jamás alcançan la fabiduría perfecta" ${ }^{56}$

Visto emos, en breve, aquella palabra que nos dixo el rey David: aora, declarado se a quál fuere el aora de los ángeles, quán breve y quán açelerado, y quán piadoso fue el Señor con nofotros hombres rudos y flacos, vestidos del saco ${ }^{\mathrm{m}}$ de tierra pesada, que ef nuestro cuerpo. Sigamos los avisos que este sancto profeta nos da y veamos que ${ }^{\mathrm{n}}$ son las cosas que emos de entender.

\section{CAPÍTULO $2^{\circ}$ \\ CÓMO DE DIOS, REY SOBERANO, TIENEN LA DIGNIDAD LOS REYES}

[Prov. 8] Per me reges regnant ${ }^{57}$, "por my, dize la fabiduría divina, tienen el dominio los reyes". El profeta David dio avifo a los-señores que aora trabajen de entender y sobre estas palabras a de yr fundado este primero tratado, según ya diximos, y porque el prínçipe a de tener muchas y grandes consideraçiones, digamos la primera en la qual va mucho; y es que conozca tener superior en el çielo, dado que no le tenga en la tierra. De mi mano, dize el Rey de los reyes, nuestro Salvador Jesuchristo, tienen los empe// [f. $3 v$ ] radores y señores reçibido el señorío que poseen, y mis súbditos y ministros son. Esto quifo nuestro Dios perfuadir a los hombres desde el principio del mundo con manifiestas razones. Cría Dios a Adán ${ }^{58}$ y no dentro del parayfo terrenal, sino fuera, y después de criado llévale a un vergel muy graciofo, plantado de árvoles y frutales de diverfas frutas y proveydo de

56. 1 Cor 1,21 y 2,6 , etc.

57. Prov 8,15.

58. Gen 2, 7-22.

$\mathrm{m}$ saco $\mid$ seco $B$

$\mathrm{n}$ que son las cosas $\mid$ om $\mathrm{B}$

o 2 | II B. 
corrientes muy aplazibles de aguas; allí le da el señorío de las aves, de las bestias, de la tierra y de los peces de la mar; dízele que coma y goze de todos aquellos frutales y folo uno que se llamava árbol de la çiençia del bien y del mal aparta el Señor como para sí, mandándole fo pena de muerte, que de aquel no coma ni le tenga como por suyo. Veis aquí puesto en fervicio al primero Rey y Monarca que uvo en el mundo y cómo por quatro cosas le enseña a la clara que su dominio le tiene de mano agena, y que Dios que se le da es su Superior. Lo primero, porque quando Adán abrió los ojos del entendimiento y se vio tener ser natural, bien vio que él no se hizo, sino que Dios por su bondad le avía criado, también conoçiendo ser llevado al parayfo terrenal luego se vio que era estranjero y no formado su cuerpo en aquel lugar y de aquella tierra; lo terçero, trayéndole el Señor todas las cosas delante para que les pusiese nombre, no pudo ygnorar ser el vifo rey defte mundo, puesto por mano de aquel alto Rey celestial, nuestro Dios. Finalmente no le dando todo aquel vergel [f. 4r] para que de todos los árvoles comiese, $\mathrm{si}<\mathrm{n}>$ quitarle uno, declaró la divina Bondad que no lo avía ${ }^{\mathrm{P}}$ por el árvol; pues tantos millares de árboles le dava en aquella deleytosa floresta, sino por le intimar por muchas vías que tenía Señor a quien obedeçiese, y que devía reconoçer sujeçión a quien tanto le avía enriqueçido y dignificado.

Pues si en la ley de Escritura queremos entrar, Saúl, primero rey de Isrrael que guardava ganado por los campos (1 Regum) ${ }^{59}$ ungido por el profeta Samuel y avisado que el Señor le efcogía para governar a fu pueblo; bien claro pudo entender que de la mano de Dios reçebía aquella dignidad y que avía de ser obediente a fu Señor, y obligado a darle cuenta del ofiçio que se le encargava. Considere y muchas vezes contemple el católico rey o varón y el que tiene señorío, y aún oya con atençión estas palabras, al oydo del anima le están diziendo continuamente de parte de Dios: "per mí reynan los reyes" "60; pues de la memoria desta sentençia naçe que sea diligente en $f u$ ofiçio, que con toda rectitud ordene las cofas del reyno y que con el temor de la cuenta, viva siempre en cuydado. Al contrario, del olvido y descuydo en cofa tan importante viene la ingratitud para con Dios, el menospreçio de cumplir la voluntad divina, la presunçión y arrogançia, y finalmente de aquí naçe el poco amor con los vasallos y el mal tratamiento de los pobres. San Pablo queriendo más estender esta amenaza y hablar con cada uno de los hombres dize anfí: "Dime hermano ¿qué posees que no ayas reçibido? Y si lo

59. $1 \operatorname{Reg}(1 \mathrm{Sam}), 9,10$.

60. 2 Prov 8,15 .

p avía I había C, hacía $B$ (en nota). 
tienes de mano agena, ¿de qué te glorías?" ${ }^{61}$. Bien conçiertan estas palabras con las que primero dixo Salomón, porque no fólo los señores de la tierra tienen el señorío de mano del [f. 4v] Rey de gloria eterna, nuestro Dios, más aún an reçibido todo lo que son y poseen; bienes temporales y naturales, $y$ los espirituales que son las virtudes, en manera que nada tiene el hombre que no sea en prestado y de que no aya de dar cuenta al dador liberal que tantos bienes le dio. Razón, pues, tiene el apóstol de hablar con algunos olvidados destos ${ }^{9}$ benefiçios y descuydados en dar gracias a Dios por ellos: "Dime, hermano, myo, ¿por qué eres agradeçido a tu Dios? ¿Qué tienes que no sea reçibido de aquella franca y liberal mano?" ${ }^{62}$. La salud, las fuerças, la vida, él te la dio y aora te la está dando, porque el conservar alguna cofa, dizen los filósofos, es obrarla. Esos bienes y riquezas del cuerpo y del alma, todo te viene de acarreo, de tu parte, lo que es, nada tienes; el ser flaco y pecador, el saber errar y andar perdido, esto tiene el hombre de su propio caudal, bien como hijo y seguydor de vanidad y aún mejorado en ella.

(Ps. 83 et 43). De aquí es que el fancto rey David tantas vezes en sus pfalmos dize una misma palabra llamando a Dios, "Señor fuyo, rey fuyo y Dios fuyo" "63. Todo esto es un reconocer que no folamente el reyno le dio de su mano, desechando a los otros fus hermanos y eligiéndole a él; fino porque en llamarle Dios suyo, reconoçe ser criatura hecha de fus manos, dándole título de rey y fuyo, le alaba por le aver hecho cabeça del pueblo de Isrrael confesando que es su Señor; declara que lleva su falario y que tiene gran obligaçión a obedeçer sus mandamientos; de arte que todos emos de confesar y considerar tres cosas para no ser notados de ingratitud: la primera, que nuestro Dios nos crió y le devemos todo [f. 5r] el ser que tenemos, como un vafo, ef hechura de las manos del artífiçe que le hizo y se deve todo a su hazedor, sirviéndole hasta que se quiebre en fu serviçio; lo segundo, el hombre a de entender que $f u$ Señor ef el que le crió y no apartarse de $f u$ voluntad, como fiervo leal en todo; lo tercero, tiene de reconocer por su Rey, al Rey de los çielos, entendiendo y teniendo muy firme en su coraçón, que debajo de tal favor y amparo, nadie le podrá derribar, ni vençer; porque ni el mundo, ni el demonio, ni la carne, no pelean con nofotros folos, sino an lo con la Magestad infinita; mueven batallas contra Jesuchristo, nuestro Rey, el qual en un punto fabe y puede y quiere desbaratar fus artes y marañas, derribando las fuerças de nuestros contrarios, dándonos las vitorias en las

61. 1 Cor 4,7 .

62. Ibid., 4,7 con algo de glosa.

63. Ps. 43,2 y 83,4 .

q destos I de estos B y C. 
manos. Moysés dijo al pueblo de Isrrael: "no temáis que el Señor peleará por vosotros y vuestro ofiçio será mirar" ${ }^{64}, \mathrm{fi}$ los ojos de la fe no cerramos y fi la esperança nuestra está firme en el Señor, como por testigos estaremos en la guerra contra nuestros contrarios y Él vençerá por nofotros, como aquí prometió Dios por su profeta.

Y porque los prínçipes, grandes señores, tienen más neçe fidad del favor deste Soberano Rey, aunque todos también le tenemos, da el avifo efe mismo Emperador del çielo y dize: "Los reyes por mí y de mi mano tienen sus reynos: el primado y monarchía del çielo y de la tierra mío es; yo doy los çetros a los emperadores; yo reparto las coronas a los reyes y distribuyo las If. 5v] varas a los juezes; a my se me deve la honrra de todo, y yo tengo de afentarme a refidençia con todos" ${ }^{65}$.

\title{
CAPÍTULO TERÇERO ${ }^{r}$ \\ DEL GRAN REYNO DE NUESTRO REDENTOR JESUCHRISTO
}

(Ps 23) Dominus virtutum ipse est rex glories. "El Señor de las virtudes del çielo, Él es el rey de la gloria" " 6 . Palabras son de aquel sancto rey David, adonde nos eforta y declara la gran magestad y poder admirable de nuestro Rey y Señor Jesuchristo. Llamava a las puertas del limbo aquella alma bienaventurada unida al Hijo de Dios y dezía: "Abrid príncipes de las tinieblas efas puertas" ${ }^{67}$. Ellos haziéndosele de mal preguntaban: ¿Quién es este Rey de la gloria? Como si dijeran: "Rey de sobervia acá le tenemos en este infierno, príncipe tirano, malo y capitán de malos, no sería cosa nueva en este desventurado lugar; más que venga a este reyno de miseria, Rey de la Gloria y de bondad, maravíllanos mucho dezidnos ¿quién es? Dávanlos respuesta: "sabed que el Señor, que tiene mando sobre las virtudes y dominaçiones, éste es el Rey de la gloria" ${ }^{68}$.

Si ya el príncipe christiano a ufado el aviso que el capítulo pafado enseñó, considerando que tiene Rey superior, de cuya mano recibió el señorío

\author{
64. Deut 32,40 y 33,27 . \\ 65. Prov 8,15-18. \\ 66. Ps 23,10 . \\ 67. Ibid., 23,9. \\ 68. Ibid., 23, 10 con glosa o comentario.
}

r Tercero | III B, 3 C.

$\mathrm{s}$ glorie I gloriae B y C. 
que tiene; aora ef menester que entienda el poder y gran dignidad deste Rey de los reyes, nuestro falvador para que más le tema y ame, reverençie y obedezca. Su título es tan único que a nadie le puede convenir, sino a fólo el Señor de las virtudes y Rey de la gloria. Quien sea señor de alguna parte de la tierra, bien fe halla acá en el suelo; quien mande a los hombres y se sirva de hombres, no es cofa nueva; mas quien tenga señorío sobre los espíritus celestia// [f. 6r] les y tenga cuenta con los cherubines y ángeles, no hay más de uno, que es el Hijo de Dios, falud de nuestras ánimas, este ef virtud y fabiduría del Padre, uno con Él en esençia, aunque otro en persona; es el que dixo para declararse quien era; "Yo y mi Padre una cofa somos" ${ }^{69} \mathrm{en}$ dezir, una cosa, declaró ser una la efencia y una la sabiduría, una la eternidad del Padre y del Hijo; diziendo somos, dio a entender la diverfidad de las perfonas: Padre y Hijo. Según declara nuestro Padre sancto t Agustín ${ }^{70}$, destas dos perfonas divinas resulta el Espíritu Fancto, amor del Padre y del Hijo, los quales le comunican por vía de voluntad todo su ser y su bondad y eternidad; tres perfonas fon y un Dios verdadero. Tal es el Rey que adoramos y el Señor a quien servimos los christianos, gente santa y muy avisada sobre todas las naçiones del mundo, "gente como dize fan Pedro (Petri) ${ }^{71}$, efcogida y real sacerdote", porque no fólo nuestro Falvador ef Rey, más aún ef nuestro Sacerdote, nuestro sacrifiçio y nuestra ofrenda en ese altar de la cruz, ofrecido para nuestra falvaçión. San Juan en su Apocalipsi<s $>$, quando vio a este poderofo Rey, dize que traya en el muslo de su divinidad, que todo el mundo sustenta, una Escritura (Apoca. 1) ${ }^{72}$, que dezía: "Este es el Rey de los reyes y el Señor de los señores. Lo mismo afirma que tenía efcrito en la vestidura con que estava vestido. ¡Oh admirable secreto! No una vez, sino dos estava una misma cosa efcrita; porque, aunque una es la perfona divina en Christo, las naturalezas fon dos: Dios y hombre, y como en aquella humanidad sagrada sea como ropa con que se difraçó este Rey valerofo para entrar en la batalla y campo desta vida, está bien diçho que no fólo en el muslo, más aún en la ropa, que traya, se efcrivió este título grande [f. 6v], San Pablo anfí llamó a la humanidad de "nuestro Salvador" ${ }^{73}$, diziendo que era vestidura. Fue hallado el Hijo de Dios vestido como hombre, toda la Trinidad entendió en esta obra, porque el poder y faber de todas las tres perso-

69. Jn 14,10 y 17,21 .

70. S. Agustín, De Trinitate, V, 14,15. Edic. por L. ARIAs (Madrid 1948) 422-23. Desarrolla esta idea también en otros lugares de sus escritos.

71. 1 Pet 2,9 .

72. Apoc 16,19 .

73. Tit 2,11 y $3,4-5$.

t sancto I san B y C. 
nas uno ef; mas el vestido, quiere dezir el Apóstol, ni es el Padre ni tampoco el Espíritu Fancto, sino solamente el Hijo (simile) ${ }^{74}$, como si uno se vistiese y le ayudasen dos: todos toman de la ropa y uno queda vestido. Esta santíffma humanidad subió tanto y alcançó tan gran dignidad por ser perfonalizada, no por sí misma, sino en la perfona divina, que viene a comunicar y partiçipar de los títulos de Dios; anfí vemos que si una labradora se cafa con un emperador, siendo antes pobre, es luego rica; siendo de baxo linaje es luego noble y generofa. Finalmente por respeto del desposorio, la que era labradora ef ya gran señora y emperatriz; anfí le acaefçió a la humanidad del Hijo de Dios, y por tanto comunica y trae escrito: "Rey de los reyes y Señor de los señores" 75 . Aquel hombre, Christo, crió el mundo porque e $f$ verdadero Dios. Él es Señor del çielo y de la tierra, y lo manda todo y por $f u$ voluntad se rije. El apóstol san Pablo," qüueriendo más declarar este señorío de nuestro Salvador, dize que ef monarcha de tres reynos por los quales se entiende todo lo criado en el nombre de Jesús: "todos <le> hinquen las rodillas en el çielo y en la tierra y en el infierno, y toda lengua confiese que nuestro Señor Jesuchristo está en la gloria del eterno Padre" ${ }^{76}$. Mucho se goza nuestra alma de oyr grandezas de tal Rey y Señor y quanto más pienfa su gran poder, más confía, siendo afligida y molestada de sus enemigos. Levantemos aquí un poco los ojos del entendimiento y contemplemos e $<$ s $>$ tos tres reynos y las leyes con el [f. 7r] este soberano Rey los govierna y rige. Sabiduría divina ef y bien sabrá governarlos; poder infinito es y podrá ${ }^{\mathrm{V}}$ bien con todos juntos. Justos es y en cada reyno pondrá leyes ordenadas con toda $1: c$ titud y justiçia. En el çielo reyna por gloria, enfeñándose quien es en $f u$ efençia a los bienaventurados; anfí ángeles como hombres, por esto dixo san Juan que aora "somos hijos de Dios" "7, aunque no sea pareçido nysonos, mas quando se declare, entonces veremos a nuestro Dios como Él es. Quiere dezir que en tanto que no poseemos aquella herençia, que el Hijo de Dios ganó a sus predestinados, que nos suframos en este destierro, adonde el mundo nos maltrata y perfigue; porque venido aquel buen tiempo, quando entraremos en el çielo, allí nuestra pobreza se volverá riqueza sinfin; nuestro trabajo se convertirá en regalo, y nuestra muerte dará fruto de vida, cofa ef

74. Se pone, en nota marginal, Simile, para indicar que se trata de una especie de semejanza o comparación, utilizando otros textos de san Pablo.

75. Apoc 16,14 y 1 Tim 6,15 .

76. Filip 2,11.

77. 1 Jn 3,1 .

u le ladd. B y C.

v. podrá I probrá $\mathrm{B}$, podrá $\mathrm{C}$. 
muy digna de confiderar, y aún de traer siempre delante $<$ de $>$ " los ojos, qué paz, qué alegría, que contentamiento tienen los fanctos gozando de aquella hermosura y bondad deste poderoso Rey Jesuchristo, los quales siempre se exerçitan en cumplir dos leyes: la una ef amor a Dios, de todo su coraçón y fuerzas; la otra es amar al próximo como a sí mismos. ¡O leyes sanctas, estatutos suaves de cumplir! ¡O pramáticas bien de tal rey ordenadas, el qual tiene por nombre caridad! Siendo amor el Rey que en tal reyno reyna, tales avían de ser fus leyes y no otras.

El otro reyno de Christo, nuestro Salvador, adonde ef obedeçido y de rodillas le adoran todos, aunque a su pesar, [f. $7 \mathrm{v}]$ es el infierno. La ley que allí se guarda, ef de rigor y de justiçia, porque tal tratamiento mereçen los moradores de tan desventurado reyno, governarlos eis Señor con "vara de hierro" "78 dezia el rey David; y anfí como a vafos de tierra los quebrantaréis. En la vara de hierro se denota la severidad de aquel fuego y la estremidad del frío; la visión de demonios y las lágrimas continuas sin fin, que an de tener, para gente tan porfiada en pecar y tan perdida en errada, vara de hierro-ef menester; con la qual sean regidos y como cántaros de lodó quebrantados. Amaron no más de la tierra, en ella buscaron sus riquezas, sus honrras $\mathrm{y}$ con $<$ ten $>$ tamientos $\mathrm{x}$; menospreçiaron el çielo, hechos pecados de lodo vil, justo ef que la vara de justiçia divinal los atormente y quebrante como a vafos de yra y de abominaçión.

Finalmente nos dixo san Pablo ${ }^{79}$, encareçiendo el gran señorío de nuestro gran Rey, Jesuchristo, que tiene dominio en otro reyno que es la tierra, èn este reyno ordenó la divina clemençia que se intimase ${ }^{\mathrm{y}}$ una ley muy a nuestro gusto y a nuestro provecho, la qual es ley de misericordia. Esto ef lo que el profeta David nos enseña diziendo: "La tierra está llena de misericordia de Dios" ${ }^{80}$. Las dos leyes que se guardan en el çielo según ya diximos, que son: amar a Dios y al próximo, también acá las guardamos aunque no con la perfeçión que en aquel reyno çelestial. Mas como seamos inclinados a pecar y por nuestra flaqueza tantas vezes quebrantamos estas leyes de Dios, ordenó con gran piedad que de nofotros tuvo este piadoso Señor una ley de clemençia [f. 8r] y es que el pẹcador sea recebido y perdonado, si de coraçón se conviertiere y se bolviere a su Dios. Esta ley escribió el profeta Ezequiel ${ }^{81}$

78. Ps 2,9 .

79. Col 1,16 y $E$ ph 1,21 .

80. Ps 32,5 y 118,64 .

\footnotetext{
$\mathrm{w}$ de $\mid$ add. B y C.

$\mathrm{x}$ contamientos I contentamientos $\mathrm{B}$ y $\mathrm{C}$.

y intimase l estimase B y C.
} 
(Eze 18) por el qual promete el Señor que en gimiendo el culpado las ofenfas que hizo, y enmendado su ${ }^{z}$ vida, que le perdonará y aún con olvido de las ofenfas que le hizo.

Ya tenemos visto en breve la grandeza del Señor que nos govierna, ya terná < tendrá> entendido el rey christiano quan poderoso ef el que le pufo y escogió para reynar. Obedézcale como a fu verdadero Señor, témale como a poderoso, que puede dar castigo eterno; y ámele como a padre de misericordia; pues con tal ley de clmençia govierna toda la tierra, perdonando pecados y dando favores a los pecadores que hacen penitençia.

\section{CAPÍTULO Q̈ÜARTO ${ }^{\text {a }}$ \\ DEL OFIÇIO QUE A DE TENER EL PÍNCIPE CHRISTIANO}

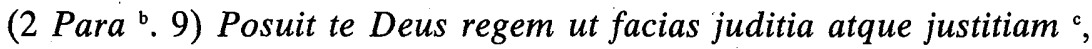
"Hízote Dios rey para que hagas juyzio y justiçia ${ }^{82}$. Después de aver la reyna Sabá venido de tan lexas tierras con deseo de ver y conoçer, si era verdad la gran fama de Salomón, que tan afamado era en toda la tierra por su gran sabiduría; aviendo conoçido y confesado por su boca esta reyna prudentíssima, que aún la mitad de lo que ella avía conoçido de las virtudes y fabiduría de Salomón no le avían dicho en fu tierra, admirad a y quafi ${ }^{\text { }}$ fuera de sí dixo ser bienaventurados los que servían a tal rey y estaban en fu presençia oyendo sus palabras, y concluyó diziendo que Dios amaba mucho a I frrahel, pues tal rey avía puesto en aquella naçión y declarándole para qué le avía dado aquella dignidad real, dixo estas palabras: “'O Salomón! No ygnores tu

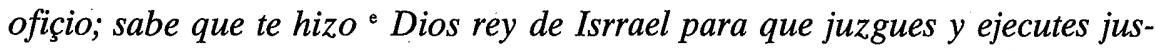
tiçia" ${ }^{83}$.

81. $E z$ 18,21.

82. 2 Par 9,8 .

83. Ibid., 9,5-8.

z sulen $B$ y C.

a Quarto I IV B, 4 C

b. Para ! Paral B.

c justitiam I justitias B y C.

d quasi I casi B y C.

e te hizo I hízote $\mathrm{B}$ y $\mathrm{C}$. 
[f. 8v] Si ya el prínçipe christiano, según avifó el profeta David, entendió que de la mano de Dios reçibió la dignidad y el reyno y si consideró el gran poder y señorío del Señor que le subió a tan alta dignidad; pues no menos que de tres reynos, çielo y tierra y infierno, es prínçipe nuestro Salvador Jesuchristo, de quien son vafallos todos los reyes y señores; aora conviene que sepa qué fin a de ser el suyo, y cómo no en vano, sino para gran provecho de la comunidad, ordenó la divina sabiduría que en cada reyno aya uno que mande y sea Señor; si bien confideramos esta cafa de Dios, este univerfo tan acabado y tan primo, todo le hallaremos concertado y ordenado, como dize la Sancta Efcritura, "a peso y número y medida" ${ }^{84}$. El peso de cada cosa, dize nuestro padre [san Agustín] ${ }^{85}$, es la virtud que Dios le dio y anfí vemos ni ay yerva, ni piedra, ni estrella, que no tenga su particular virtud, que le dio Dios, dándole el ser; manifiéstase esto en las diversas maneras de mediçinas, las quales de rayzes y yerbas y semillas son ordenadas para salud del cuerpo. Tienen todas las cosas número: los elementos son quatro, los çielos son diez y no más, los planetas siete, finalmente esa multitud de estrellas que vemos, aunque nos parecen tantas y sin cuento, el rey David dize que "las tiene el Señor contadas y que a cada una pufo nombre" ${ }^{86}$. La medida tampoco falta; porque la grandeza del çielo y de la tierra limitada es, y nada puede ser infinyto, sino el que todo lo crió y hizo de nada; pues si anfí ef que todas las cofas tienen orden, andan a peso y medida en la cafa de Dios, y los elementos tiene supe// [f. 9r] rior que es el fuego asentado en el más alto lugar, sobre el ayre, agua y tierra y sobre todos los çielos está el impíreo ${ }^{\text {f }}$, que a todos excede en lugar perfeçión, el qual es lugar de los bienaventuados: entre las aves, el águila; entre los anymales, el león es el rey de los animales; no era razón que lo mejor deste univerfo, que son los hombres careciesen deste privilegio. ¿En qué entendimiento cabe que la república de las abejas tengua rey, a quien acompañe y siga, y que la república humana, tan dotada de entendimiento y razón, esté sin guía a quien siga, y sin rey a quien ovedezca?

El ofiçio del prínçipe es el de la cabeça, en la qual están los ojos, como atalayas para enseñar el camino a los pies y para que las manos açierten a obrar. Anfí le pintó nuestro Dios al primero rey de Ifrrael, Saúl, a quien

84. Prov 20,10

85. S. Agustín, De Gen. ad lit. IV, 3,7 (PL 34,299) y Confes. 13,9 (PL 32,849) etc. Estas ideas son claves en el pensamiento filosófico, jurídico y político de Alonso de Orozco y de fray Luis de León, a quien siguen Pedro de Aragón y otros agustinos de la Escuela de Salamanca. L. DE LeÓn, De legibus, "Introducción" por L. PEREÑA, XXIII-XLIII.

86. Ps 147,4 .

f impíreo l empíreo B y C. 
dixo: "Cuando eras pequeño en tus ojos, púsete por cabeça de Isrrael" ${ }^{87}$, quiere dezir el Señor, mira que estás en lo más alto y que la dignidad real a de exerçitarse en mirar a todas partes y como la cabeça encamina todo el cuerpo, anfí el rey a de guiar y governar todo su reyno. En la cabeça resplandeçe más la virtud del ányma, porque allí están allegados y hermanados todos los çinco sentidos, y anfí en el pínçipe an de estar todas las virtudes; pues a de ser espejo a todos y dechado de quien todos aprendan, siendo tal y tan acabado a se de exerçitar en hazer juizio y justiçia. El juzgar declara la fabiduría y prudençia que a de tener y el hazer justiçia la fortaleza y ánimo que a de enseñar para ser de los malos temido. Para lo primero, que es juzgar, se requiere gran avifo y diligençia, anfí para inquyrir oyendo las partes, como para buscar indiçios, los [f. 9v] quales suelen ser más baftantes que las palabras; cofa fue que mucho espantó aquella sentençia que dio el rey Salomón ${ }^{88}$, no por lo que oyó a los teftigos, sino por lo que la prudençia le enseñó. Vinieron dos mugeres delante de la justiçia y la demanda era cofa estraña. Avían las dos parido cada una un niño, y acostadas con sus niños en sus braços, la una madie ahogó su propio hijo; depertando, como vio el mal reçaudo que avía hecho, quytó a fu compañera el niño bịo y púfole el muerto; reconoçiendo quando despertó que aquel no era su hijo, vio en - * der de la otra su niño bivo y en fu braço el hijo ageno defunto ${ }^{\mathrm{g}}$. Vanse d hante del rey, comiença la agraviada a contar el cafo afirmando que la otra le avía robado su hijo. La parte negaba con gran porfía y no avía otros testigos; manda el rey traer una espada y que se dé a cada vna la mitad del hijo que entranvas pedían. La que no era madre consintió la sentençia y dixo en buen oro, como madre fingida y no verdadera; al contrario, la madre natural, movida a compasión apeló de la sentençia y dixo, ¡Oh señor!, no se parta el niño, quédese con él y biva. De aquí entendió el sabio rey quál era fu madre y entonces mandó que se le diese su hijo.

Deste exemplo entenderán los reyes cómo an de hazer efamen, soliçitando maneras y medios, por los quales saquen çertinidad en lo que está dudoso, no sentençiando sin bastante provança, porque de otro arte no se haría justiçia, sino injustiçia y agravio en las repúblicas. Nuestro Dios, fabiduría infinita que todo lo ve y sabe, no sentençió a nuestros padres primeros sin los oyr y tomar su dicho primero, no porque era menester provança para cofa tan clara en los ojos de Dios, tan manifiesta dentro de sus conçiencias

87. 1 Sam 15,17 .

88. 1 Reg 3,16-28.

$\mathrm{g}$ defunto I difunto $\mathrm{B}$ y $\mathrm{C}$. 
de ellos; [f. 10r] mas para que enseñase a los prínçipes, que primero se a de hazer juyzio y probanca, que se ejecute la justiçia; quifo el criador de los çielos asentarse a cuenta con Adán y Eva, antes que los desterrase el parayfo y los condenase a grandes trabajos y penas, gran orden llevan estas palabras que esta reyna sabia dixo a Salomón: "juzgar y justiçiar" ${ }^{89}$. El que justiçia y no juzga, tirano es rigurofo y gran agravio haze al que sentençia; y el que juzga ser digno de castigo el malhechor y no ejecuta, pufilanime es y flaco, salvo si alguna causa bastante no le mueva a usar de clemençia. El ofiçio del rey católico es, a la manera de ${ }^{n}$ médico, trabajar de conservar a fus vafallos, según nos avifa el philófofo ${ }^{90}$; mas quando el brazo está cançerado o fistulado, mejor es que se corte que no que infiçione todo el cuerpo. San Pablo dize que "no sin causa trae el que es ministro de justiçia espada en la mano" ${ }^{91}$, meneste ef para castigar a los malos, para confervar la paz y para dar favor a los virtuofos; excelente cofa es y de gran valor la dignidad real; pues la justiçia pereçería, los pecados yrían muy adelante y las virtudes perecerían si no ubiese prínçipe, que fuese a la mano a los malos y diese favor a los buenos.

\section{CAPÍTULO QUINTO ${ }^{i}$ COMO EL REY A DE ENSEÑOREAR A $f$ Í MISMO}

( $3^{\mathrm{j}}$ Regum 11) Regnabis super omnia que desiderat anima tua, erisque rex super Ifrrael. "Reynarás sobre todo lo que desea tu ánima y serás rey de Ifrrael" ${ }^{92}$. Esto <lo> ${ }^{k}$ dixo el profeta Abías a Jeroboán, hijo de Nabaht Efrateo, queriendo Dios castigar al rey Salomón, el qual olvidado de tan grandes benefiçios, adoró [f. 10v] dioses vanos o por mejor dezir, demonios desimulados. Manda el Señor a este profeta que divida su manto que tray nuevo, en diez partes y que las dé a Jeroboán y que le diga cómo reynará

89. Ibid., 10,9 .

90. El filósofo es Aristóteles, al que cita tres veces en el Príncipe christiano y más frecuentemente en Regalis Inftitutio.

91. Rom 13,4.

92. $1 \operatorname{Reg} 11,37$.

$\mathrm{h}$ del médico I de medios $\mathrm{B}$ y C.

i Quinto / V B, 5 C

j $3 \mid 2$ B

$\mathrm{k}$ lo $\mid a d d$, $\mathrm{B}$. 
sobre diez tribus y que solamente poseerá Roboán ${ }^{93}$, hijo de Salomón al ${ }^{1}$ $<$ la> tribu de Judá; esto por el gran respecto ${ }^{m}$ que Dios tuvo a $f u$ siervo David, tan amado y privado suyo; en manera que como candela encendida, quede de su linaje esta memoria y no del todo se acabe su reyno y linaje, de donde entendemos la gran justiçia de Dios, que castiga los pecados de los padres en los hijos con penas temporales y también conoçemos la misericordia excelente de nuestro criador; pues se acordó de los serviçios del sancto rey David ${ }^{94}$ y no olvidó la promesa que le avía hecho, diziendo que nacería el Hijo de Dios de su linaje, por efo queda con el señorío del tribu $<$ to $>{ }^{\mathrm{n}} \mathrm{de}$ Judá Roboán, heredero de Salomón y no fue despojado del todo.

Declarando a nuestro propósito estas palabras que Abías dixo a Jeroboán, al qual profetizó que reynaría sobre todas las cosas que su ánima deseava, diremos: que ${ }^{\circ}$ el prínçipe christiano a de tener tres señoríos y governaçiones: lo primero, a se de gobvernar a sí mismo; los segundo, a de regir su cafa; lo terçero, a de regir su reyno. Cofa grande es que el que tiene governaçión temporal o espiritual, aproveche a los otros, gane ánimas de sus hermanos y súbditos; mas ¿qué le aprovechará al fin para con Dios, aver trabajado y ganado todo el mundo, si a sí mismo no se supo ganar y regir? ${ }^{95}$. Nuestro Salvador haze esta pregunta dando a entender que el provecho en los otros a de comencar [f. 11r] de nofotros mismos. Lleva tanta razón esto que aún el fiłófofo lo alcançó quando dixo: "que la amistad y buen tratamiento que hazemos a nuestros amigos, naçe del amor que tenemos a nofotros mismos" (Ethi. 9) ${ }^{96}$. En manera que como del amor bien ordenádo, que yo me tengo amí, naçe el amor y amistad que tengo a mi amigo, anfí de la buena governaçión y conçierto que cada un christiano tiene configo mișmo, resulta que sepa y pueda regir a los otros también; persuade esto la esperiençia en las cofas naturales, a las quales vemos que proceden y tienen prinçipio comenzando de lo que es menos a lo que es más; van adelante saliendo de lo que ef imperfe $<\mathrm{c}>$ to y llegando a lo perfe $<\mathrm{c}>$ to. Primero, un árbol nace como yerva, después crece y sube alto y da fruto. Primero el hombre ef niño pequeño y con la edad llega a ser perfecto varón. Bien anfí a de comencar el príncipe $\mathrm{o}$ perlado ${ }^{\mathrm{P}}$ a governarse prudentemente a sí mismo, que es menor

93. Ibid., 11,28-36.

94. $2 \operatorname{Sam} 7,12-14$.

95. $M t 16,26$.

96. Aristóteles, Ethica Nicomáquea, 9,8, trad. por Julio Palli Bonet (Madrid 1985) 366-69.

1 al I la B y C.

$\mathrm{m}$ respecto $/$ respeto $\mathrm{B}$ y $\mathrm{C}$.

n tribu I tributo B y $\mathrm{C}$.

o que lom. B y C

p perlado | prelado B y C. 
virtud y arte, que no regir una cafa, y después yr subiendo como por grados, hasta venir a regir todo un reyno, a donde es menester mayor fuerça, saber y prudençia.

Dize, pues, el profeta Abías, anfí como hablando con cada uno de nofotros: "Reynarás sobre todas las cosas que tu ánima desee y serás rey de Isrrael" 97. Censo es y tributo harto pesado el que nos encaminó el pecado de Adán, el qual por su rebeldía y desobediençia ${ }^{q}$ nos perdió aquel reyno pacífico y imperio maravillofo concertado por la mano de Dios; sentimos poco esta pérdida porque la consideramos poco; que bien ${ }^{\mathrm{r}}$ creo que si como gente fabia y avifada lo miráfemos, que nuestro ofiçio sería en esta vida llorar y gemir la pérdida de un mayorazgo tan rico, imperio tan preçioso como Adán nos perdió; grande cosa era [f. 11v] el ser señor de las aves, animales y peçes del mar; mas yo en poco tuviera esta pérdida con que no quedáramos en la guerra y batalla continua que traemos y cada día sentimos dentro de nofotros mismos. Llorávalo san Pablo y dezía "que nuestra flaca carne desea contra el espíritu y espíritu pelea deseando contra la carne" ${ }^{98}$. Los que andan en esta batalla tan brava, son los dos hombres nuestros, el exterior y el interior, tan hermanos y tan enemigos, tan unidos en unidad de lugar y tan apartados en voluntad; las faetas y lanzas son los deseos contrarios s; quiere el cuerpo como tosco y grosero las cofas senfuales y visibles, porque ni sabe más ni ve más; desea riquezas y honrras vanas; busca con gran agonía pafatiempos y deleytes; anfí como aldeano grosero que es natural desta aldea en que bivimos. Mas el ánima criada-a la ymagen de.Dios, el espíritu noble y çiudadano que a de ser del çielo, ni se ceva de oro ni plata, ni se agrada de honrra afentada sobre el ayre; ni tampoco para el pafatiempos, que ${ }^{t}$ son comunes con las bestias de comer, ni bever, ni otros regalos de los sentidos. Espíritu es y no quiere ny descanfa sino en aquel espíritu divinal, piélago de infinitas perfeçiones que es Dios:

Véis aquí a los dos hermanos que pelean, aún antes que sean naçidos: Esaú y Jacob; admírase Rebeca ${ }^{99}$, su madre, y váse a confultar con Dios sobre tan estraño negoçio y respóndele el Señor que dos cabeças de vandos o dos pueblos diverfos andan en batalla, y que el mayor a de servir al menor:

97. $3 \operatorname{Reg} 11,37$.

98. Gal 5,17.

99. Gen $25,22-23$.

q desobediencia / obediencia B.

$r$ bien I también $B$.

$s$ contrarios I contra Dios B y C.

$t$ que | no $B$. 
Esaú a Jacob. Aquí enfeña Dios quién a de ser rey de los dos hermanos que dentro de nosotros pelean; no Esaú, el mayor, que nace primero, no ha de mandar el [f. 12r] cuerpo que por algunos días es organizado, antes que el ányma sea criada y infundida; vase formando el cuerpo y creçiendo cada día, hasta ser perfectamente dispuesto y organizado; y entonçes en un instante Dios cría el ánima y la infunde, y esto es aquel alentar Dios en el rostro de Adán y quedar hombre perfecto con ánima raçional; por manera que Jacob, nuestro espíritu, hermano menor, a de mandar; y el cuerpo, hermano mayor, a de servir. Reynar el hombre sobre todas las cofas que desea su ánima, es tener debaxo del pie todos los apetitos de la carne y cumplir lo que Dios mandó a Caín, quando le dixo: "Debaxo de tu dominio terná tu deseo y tú le enfeñorearás" (Gen.) ${ }^{100}$. Mucho puede la sensualidad, gran fuerça trae consigo la carne; mas la razón todo lo vence con el favor de Dios; el espíritu, como es libre, no puede ser compelido; guerreado y conbatido sí; inpertunado " y molestado puede lo ser; mas derribado, no rindiéndose él, jamás lo será.

De notar ef que dixo el profeta Abías a Jeroboán, que "avía de reynar sobre todo lo que deseava su ánima" ${ }^{101}$, y no dixo que sobre parte de ello, porque vencer un viçio y ser sujeto a otro, no es ser rey, sino siervo, claro está que el que es capitán de un exérçito haviéndole preso los suyos, no será ya capitán sino ca<u>tivo ${ }^{\vee}$ de los de su capitanía. El rey, contra quien se levantó su reyno, no se dirá reynar en tanto que le fon rebeldes sus vafallos; bien anfí diremos que el hombre ca $<u>$ tivo de sus pasiones, aherrojado de sus propios deseos, [f. 12v] dado que tenga dignidad y señorío sobre otros, no es señor de sí mismo y quán grandes tiranos sean los malos deseos y quán crueles parä el espíritu enséñalo san Pablo (Ro. 1) quando dize que "a los sovervios entregó Dios a sus deseos" 102; es dezir, diólos en las manos a los turcos. ¡Oh, qué severidad y tiranya tan grande ejecuta un mal deseo en nuestra alma, qué çentella de infierno, tan abravadora es, qué guerra tan sin çesar haze, no ay ca<u>tivo aprisionado en tierra de moros que tan mal lo pase como una mala confçiençia! Ésta es la mujer litigiofa que dize Salomón, con la qual ninguno puede hazer vida.

100. Ibid., 4,4-12.

101. $1 \operatorname{Reg} 11,37$.

102. Rom 1,24.

$\mathrm{u}$ inpertunado / importunado $\mathrm{B}$ y $\mathrm{C}$.

$\mathrm{v}$ cativo I autivo B y C. 
El que tuviere enseñoreados sus sentidos y pasiones, y sugetare a la razón todos sus penfamientos, palabras y obras, éste será rey de Isrrael, terná el primero señorío que es saverse ${ }^{\text {w }}$ governar a sí mismo; y será ábil para regir su cafa y para mandar el reyno.

\section{CAPÍTULO SESTO *}

\section{DE LAS ARMAS CON QUE EL HOMBRE A DE VENÇER A SÍ MISMO}

(Esa. 19) Rex fortis dominabitur eorum. "El rey animofo y fuerte será señor de ellos" ${ }^{103}$. El profeta Esaías declarando el señorío que avía de tener un rey fuerte sobre Egipto y el gran caftigo, que Dios a los egipçianos avía de dar por sus grandes pecados, dixo estas palabras por mandato de Dios: "Subirá el Señor en una nube ligera y entrará en Egipto, y todos los ydolos caerán en su presençia y dará guerra una çiudad a otra y peleará un hermano con otro, $y$ al fin el rey fuerte los fujetará a todos" ${ }^{104}$. San Jerónimo dize que a la letra se cumplió esto quando nuestro Salvador huyó de Herodes y la madre sagrada suya y el sancto ${ }^{y}$ Joseph se fueron a Egipto, [f. 13r] entonçes cayeron los ydolos todos de aquel reyno, porque el rey celestial estaba presente; llámafe rey fuerte a quien nadie bafta a resistir por ser infinito su poder; esta fortaleza comunicó él a sus miembros, a los quales dixo que no uviesen miedo que él avía vençido al mundo (S. Aug.) no para fí peleó y vençió, sino para nofotros, según declara sancto ${ }^{z}$. Augustín ${ }^{105}$ y anfí diremos que es mayor la fortaleza que Christo nos comunica, que no la de Adán en el estado de la ynoçençia; porque entonçes enseñoreávase de todo Adán, de las riquezas de las honrras y de todo lo demás; aora por la virtud de nuestro Salvador, no fólo de las riquezas es señor un varón christiano, más aún de la pobreza; no folamente sujeta las honrras, más aún las deshonrras; no fólo la

103. Is 19,4 .

104. Ibid., 19,1-2.

105. S. JeRÓNIMO, Comentariorum in Isaiam prophetam S. Hieronimi, liber V. cao. 19. Opera 4 (Veronae 1735) 201-2 (PL 24,181).

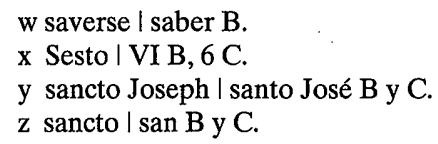


vida, más aún la muerte tiene debaxo de los pies, menospreçiándola y esto es más que la fortaleza de Adán; nadie tema que la vitoria de nofotros mismos defa ${ }^{a}$ y del mundo, ya el Señor nos la ganó.

Las armas con que emos de pelear, dize el apóstol "que no son visibles, no de hierro ni de azero, sino armas espirituales, poderofas y dadas de mano de Dios, bastantes para destruir todas las muniçiones y consejos de nuestros adversarios" $\left(2{ }^{\mathrm{b}}\right.$ Corin 10$){ }^{106}$. Tales armas a de usar el prínçipe christiano y cada uno de los fieles, las quales son tan fuertes y provadas a prueva de arcabuz que jamás faltaron al que dellas bien ufase; el efcudo es la sancta fe; el qual nos manda el Apóstol que jamás dexemos de la mano; siempre cumple traer enbraçado ${ }^{c}$ tan fuerte y resplandeçiente arma; confesando los artículos de la divinidad y humanidad de nuestro Redentor, Rey de los reyes; la cota de la justiçia nos a de fortalecer de piés a cabeza, cumpliendo todos los [f. 13v] mandamientos de Dios, que anfí como argollas o sortijas de malla, se travan unos de otros, y se fortaleçen unos con otros. "Vosotros sois mis amigos, dixo el Señor del mundo, si hiziéredes todo lo que os mando" ${ }^{107}$. No parte, no algún mandamiento o algunos, sino todos se an de cumplir para que Christo Jesús sea nuestro amigo. No sin causa dixo Sanctiago d que "el que peca en una cofa, es culpado en todas" ${ }^{108}$. Dificultofa sentençia a la verdad es ésta; pues hallaremos quien sea ladrón y no homiçida; quien sea sobervio y no avariento, ¿cómo, pues, peca en todos quien quebranta un mandamiento?

Quiere dezir Sanctiago que la ley divinal es tan delicada y tan subtil, que a la manera de una cota que rompida por sola una malla pareçe la rotura y por allí el enemigo puede herir y matar al que la tiene vestida; anfí el christiano que en fólo un mandamiento ofende a Dios, se pone a gran peligro y se abilita para pecar en todos de su parte; pues le falta ya la graçia que le hazía fuerte contra el demonio; cada-día lo vemos que una rodeçita ${ }^{e}$ de un relox quebrada, todas las otras se paran y queda destruido todo aquel artifiçio, y también vemos que el que pierde el último efcalón y más alto de la escalera, va dando de manos hasta caer en la tierra; en manera que el que [f.

106. S. Agustín, Enarratio in Sal. 102,7 (PL 37,1321). Aparece también esta idea en otros escritos del Obispo de Hipona.

107. 2 C乞r10,4.

108. Jn $15,1$.

a defa I de esa B y C.

b $2 \mid 1$ B.

c enbraçado l embrazada B.

d Sanctiago I Santiago B y C

e rodecita I ruedecira $\mathrm{B}$ y $\mathrm{C}$. 
14r] quisiere vencerse a sí mismo y pelear con sus enemigos espirituales, vale la vida que tome el efcudo de la fe católica, acompañada de charidad y que se vista la cota de la justiçia poniendo por obra la ley de Dios, el almete de la salud a de cubrir nuestra cabeza, que es lo alto de la razón, según el Apóstol avisa, y finalmente devemos tomar armas ofensivas, "una espada de dos filos que es la palabra divinal" ${ }^{109}$, desta ${ }^{f}$ emos de ufar a manera de aquel animofo Ayoht ${ }^{\mathrm{g}}$, que también peleava con la mano siniestra, como con la mano derecha; esto es dezir, que no fólo la doctrina divinal nos a de hazer fuertes, poniéndola en nuestro coraçón, en tiempo de la prosperidad; porque no nos ensoberbezcamos con los benefiçios de Dios; más aún, el tiempo de la adversidad, pobreza y enfermedad, tener delante de los ojos del alma las promesas de Dios y la invocaçión de su sancto nombre, y dando bozes como gente animofa, dezir con el profeta David (Ps.): "en vos, Señor, esperé, no seré jamás confundido, ni me rendiré a mis enemigos" " ${ }^{110}$.

Avísanos una cofa san Pablo en esta batalla espiritual y vanos mucho en la considerar; porque muchos por ygnorançia son engañados y vençidos: "nadie, dize san Pablo, piense de vestirse de las armas de Dios y de las de Sathanás" 111; necesario es que dexe las unas para tomar las otras, por tanto, desde luego. El rey católico y cada un christiano [f. 14v], que desea gozar de tan gloriosa victoria, sugetando a sí mismo y a sus pasiones al yugo suabe del Señor; cumple que "arroje las armas de las tienieblas y se vista de las armas de la luz" (Ro. 13) ${ }^{112}$. La manera del hablar el Apóstol, nos da arte cómo emos de vençer y ganar la vitoria; dize que "arrojemos las armas de las tinieblas"; cada pecado es una noche, una ygnorançia y oscuridad en el alma. Aristóteles dixo "que todo hombre malo ef ygnorante y bovo". ¡ $\mathrm{O}$ gran tontedad, ofender al criador del universo! ¡O gran grosería ser ingrato al Hijo de Dios, que tanto por matar el pecado y destruyrle padeçió! Vaya fuera el arma oscura de la yra, para que paçiençia, arma de luz, sea asentada en nuestra alma, desterremos lexos tierra toda sobervia para que la humildad nos haga fuertes y espantosos a nuestros enemigos. Finalmente todo viçio y la ocasión del arrojemos de nosotros para que el arnés de las virtudes theologa-

109. Sanct 2,10 .

110. Heb 4,12.

111. Ps 30,2 y 70,1 .

112. Rom 13,$12 ; 2$ Cor 10,4 .

f desta I de esta B y C.

g Ayoht I Ayoch B y C. 
les y morales nos hagan fuertes y armen de pies a cabeça. Con armas de luz vençió Gedeón ${ }^{113}$ y sus trezientos ${ }^{\mathrm{h}}$ hombres llevando unos cántaros en las manos, llenos de lumbre y con tal ardid, dado de mano de Dios, ganaron la vitoria ${ }^{114}$. Y de la misma manera, el capitán de un reyno todo, que es el Señor y rey de él, juntamente con sus vafallos, serán vencedores de sí mismos y de sus conquistadores ufando deftas ${ }^{\mathrm{i}}$ armas de luz, que san Pablo nos avisa que tomemos.

El rey fuerte será señor de sus enemigos, si el prinçipal venciere primero que es rendir a sí mismo a sus apetitos y inclinaçiones que le combidan por $\mathrm{el}^{\mathrm{j}}$ [mal o el pecado]?...

III

\section{APÉNDICE. POSIBLE CONCLUSIÓN}

Se pone aquí la conclusión, porque es algo que falta al texto del Príncipe christiano, y puede deducirse no sólo de lo dicho en la introducción sino también de la lectura del texto de este opúsculo, claramente incompleto. El mismo autor no se decidió a publicarlo, como lo hizo con otros tratados de la misma índole, porque no estaba terminado.

Es probable que se haya pensado en el malogrado príncipe de Castilla D. Carlos, al que dedicó la primera epístola de su Epistolario christiano para todos los estados, con seis avisos, al final, tantos como son los capítulos del Príncipe christiano, aunque no haya luego una total correspondencia. Alonso de Orozco, al tratar de los mismos temas, no solía repetirse, sino que con gran cultura y habilidad les daba nuevo enfoque y tratamiento.

$\mathrm{Al}$ escribir este opúsculo, Alonso de Orozco, según lo dice él expresamente, estaba pensando no sólo en los príncipes, reyes y señores, que tienen vasallos y señorío, sino también en cada cristiano, "el qual a de governar christiana y sabiamente su monarchía o reyno que es a fí mismo" ${ }^{115}$.

$\mathrm{Su}$ lectura es útil a todos los cristianos, como lo ha sido El Príncipe de Maquiavélo para los políticos. Su enfoque, con estilo jurídico-canónico, es instructivo y moralizador. Se marginan cuestiones técnicas sobre la ley, la

113. $\operatorname{Rom} 13,12$.

114. Juec 7,6-22.

115. Ms. A, f. 1v.

h trezientos $\mid$ trescientos B y C.

i deftas | de estas B y C.

jel | él B y C. 
justicia, la política, la potestad eclesiástica y real, que desarrolla en Regalis inftitutio. Esta obra viene a ser un complemento del Príncipe christiano y viceversa, como se ha observado anteriormente.

Los tres avisos del Rey David dan origen a los tres tratados de ambas obras con distinta formulación y desarrollo, comenzando igualmente el cap. $1^{\circ}$ con el mismo texto bíblico e insistiendo en el origen divino de la potestad regia, que se complementa en el capítulo $2^{\circ}$ de Regalis Inftitutio.

Las enseñanzas, que sé deducen del texto de David, se formulan en tres principios: $1^{\circ}$ Las cosas que han de considerar los reyes cristianos sobre su potestad y origen de la misma para cumplir la dignidad de su oficio; $2^{\circ} \mathrm{La}$ sabiduría que han de tener el príncipe y el rey en el gobierno de la república comenzando por su casa; y $3^{\circ} \mathrm{El}$ arte que para servir a Dios da el rey David o la política. Estas tres ideas son vertebradoras del Príncipe christiano ${ }^{116}$. Esto se analiza mejor y con más documentación en Regalis InftitutiQ, donde se desarrolla mejor y con más documentación la parte política, ética y económica, alterando un poco el sistema y el orden.

Los seis capítulos del Príncipe christiano se corresponden en parte con los seis avisos de la "Epístola primera" de su Epistolario christiano para todos los estados ${ }^{117}$, que vienen a ser una especie de conclusión:

$1^{\circ}$ Que los príncipes y reyes cristianos deben recordar "la unción del Rey Sancto" ${ }^{118}$, David en Ebrón, es decir, el origen divino de la potestad regia, lo que se recoge en el cap. $1^{\circ}$ del Príncipe christiano.

2. Que "los principales del Reyno fe llamaron hermanos del Rey David". Esto quiere decir, "que los Príncipes llamen a fus Vaffallos hermanos y les traten como a tales" ${ }^{11}$. Esto se expone también en el cap. $2^{\circ} \overrightarrow{\mathrm{del}}$ Príncipe christiano, poniendo como modelos a David y a Jesucristo. Se parte de que todo poder viene de Dios, algo que ratifica y repite varias veces.

3. "Que los Reyes tienen el poder de mano de Dios y fon retrato y, representación de Dios". Los reyes son viso-reyes de Dios y de Jesucristo "único Rey y nuestro Salvador" ${ }^{120}$, algo que se expone en el cap. 3. del Príncipe christiano, titulado: "Del gran reyno de Nuestro Redentor Jesuçhristo".

$4^{\circ}$ "Que el Príncipe entienda, que es Paftor en todo fu Señorío y tal título se lo dio en aquella elección al Rey David" ${ }^{121}$. El mejor modelo de pastor y rey lo tenemos también en Jesucristo. Hay otros modelos comọ Saúl,

116. Ibid., f. 1v. Cf. Supra nota 20:

117. A. DE OROZCO, Obras, I, 13-16.

118. Ibid., I, 13. col. 1 .

119. Ibid., 13 , col. 2 .

120. Ibid., 14, col. 1 .

121. Ibid., 14, col. 2. 
David y Salomón, cuya prudencia y sabiduría admiró la reina de Sabá. Esto se expone en el cap. $4^{\circ}$ del Príncipe christiano, cuyo oficio lo ejerció Salomón con su sabiduría y prudencia, especialmente en el proceso seguido entre las dos mujeres, que se consideraban madres del niño vivo. Dentro del oficio del rey y del príncipe está el saber actuar como juez, pastor y médico.

$5^{\circ}$ "Que el Príncipe Christiano, para fer buena guarda de fu Reyno ha de velar fobre fus ovejas, y no dormir" ${ }^{122}$. Para hacer esto, ha de comenzar por saberse "enseñorear" como se dice en el cap. $5^{\circ}$ del Príncipe christiano.

$6^{\circ}$ "Que el Príncipe Cathólico trayga por guarda la mifericordia y la verdad, como dice el Rey Salomón, y fe precie de clemente, porque la clemencia fortalece el trono real" ${ }^{123}$. Las virtudes forman parte "de las armas con que el hombre a de vençer a fí mismo" según se titula el cap. $6^{\circ}$ del Príncipe christiano, que insiste en las mismas ideas, aunque en parte resultan incompletas. Se puede complementar con lo que se dice en el sexto aviso.

Después de poner como modelo al emperador Carlos V, con su ejemplar muerte en Yuste, donde "acabó fu christianísima vida", hace Alonso de Orozco una recapitulación de la carta al príncipe de Castilla; Carlos, y concluye con estas palabras, que complementan al Príncipe christiano: "Todo efto podrá Vuestra Alteza en la virtud de nuestro Salvador Jesu Chrifto, fi no ceffare de orar; y fe exercitare en el ufo de los Sacramentos, Confe ffión y Comunión, medicinas de nuestras ánimas y remedio de nueftras flaquezas y desamayos. Y podrá decir con San Pablo: Todo lo puedo en aquel que me dà vîrtud y me esfuerza ${ }^{124}$. Plegue a la divina Magestad, que de tal manera $f e$ faque fruto de efta Epíftola y Documentos, que fiendo Paftor de la mano de Dios efcogido, encamine Vuestra Alteza fus ovejas a los paftos del

122. Ibid., 15, col. 1 .

123. Ibid., 15 col. 2 .

124. Fil $4,13$.

125. A. de Orozco, Obras, I, 16, col. 2. Esta conclusión es muy parecida a otra carta "A su Alteza el Príncipe " (Carlos), que es posterior a la del "Epistolario", ya que lo menciona, por lo que debería ir a su lado o después y no antes del "Diálogo entre Agustino y un Cortesano", como va en la edición de 1736, I, sin foliar, f. 3rv: "El Señor fello la lumbre de fu rostro en nuestra alma criándola a fu imagen y femejanza, fegún nos avisa el Profeta David, y no tendrá ella contento y hartura, hasta que le felle con el fello de la lumbre de la gloria, alli Vuestra Alteza tendrá contentamiento y hartura; allí hallará guardado el premio de sus trabajos, quando el Rey de Gloria, Jesú Christo, le diere trono en el Cielo para perpetuamente reynar, gozando de la vista de Dios. El qual fu muy alta y poderosa perfona guarde, y en fu fanto amor conferve por largos tiempos. Amén. Capellán de Vuestra Alteza". Se trataba de dar ánimo al príncipe, como se observó supra, nota 8. Con los estudios que se están realizando en el $I V$ Centenario de la Muerte del beato Alonso de Orozco, es probable que se pueda llegar a conclusiones más definitivas sobre esta materia. 
Cielo, para que con ellas goze de aquel Reyno perdurable de la gloria. Amén" ${ }^{125}$.

Las ideas de este último texto serían las últimas que Alonso de Orozco habría añadido al Príncipe christiano, dentro de los conceptos agustinianos de bien común, orden y armonía ${ }^{126}$. Alonso de Orozco suele concluir haciendo una recomendación a la oración, la vida de gracia y la práctica de los sacramentos bajo la influencia del Espíritu Santo con su visión providencialista y escatológica, ya que se debe actuar pensando en la vida eterna. El fin pastoralista del Derecho Canónico es la salvación de las almas.

Fernando CAMPO

126. A. DE Orozco, Príncipe christiano, cap. 4, Ms. A, f. 8v. Cf. Supra, nota 75. Tanto el beato Alonso de Orozco, como fray Luis de León, acuden a los textos básicos de las Sagradas Escrituras para probar sus asertos. Esto es común a los autores clásicos del siglo XVI, incluso también antes y después entre los escritores eclesiásticos. Por eso dice uno de los mejores teólogos dé la Universidad de Salamanca, frau Basilio Ponce de.León, en suṣ notas a las Confesiones del beato Alonso de Orozco, edic. por L. RuBio, 175: "En la Escritura y santos tan cursado, que cuando leo así estos libros suyos, como otros, se me refresca la memoria de lo que he leído en santos". Es que, además de jurista y sabio, fue un santo. T. Aparicio, Fray Alonso de Orozco, hombre, sabio y santo, 169. En esta biografía no se menciona el Libro llamado Príncipe christiano, debido a que se trata de un opúsculo bastante desconocido y al carácter divulgativo de esta publicación, donde se llega a considerar a Regalis Inftitutio (Institución Real) superior a la Historia de la Reina (de) Sabá, al afirmar que "la reina doña Isabel de Valois debió quedarse con ganas de algo parecido con dedicatoria expresa para ella" (ibid., 156). Tiene la ventaja de dar al final, como apéndice, los "principales biógrafos del beato Alonso de Orozco", (ibid., 171-72). F. CAMPO DEL POZO, "Importancia del tratado sobre El Príncipe cristiano de Alonso de Orozco", La Ciudad de Dios, 204 (1991) 75-88. Este número está dedicado al beato Alonso de Orozco con la bibliografía fundamental, ibid., 205- 54. 


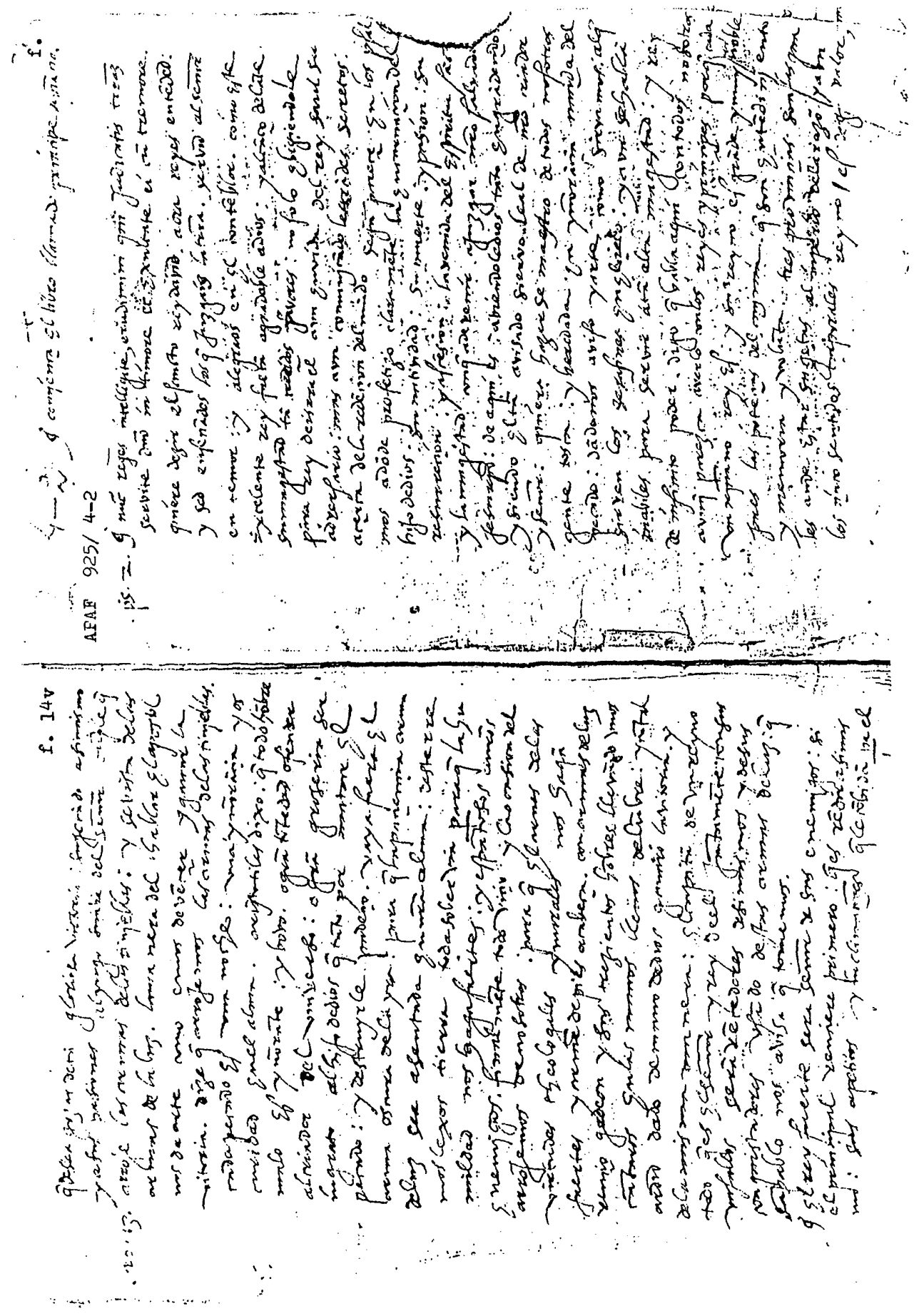

